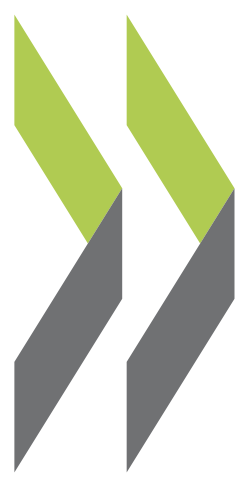

OECD Economics Department Working Papers No. 1298

Structural reforms to boost inclusive growth in Greece

\title{
Christian Daude
}

https://dx.doi.org/10.1787/5jlz404fx631-en 
Organisation de Coopération et de Développement Économiques

Organisation for Economic Co-operation and Development

13-May-2016

ECONOMICS DEPARTMENT

English - Or. English

\section{STRUCTURAL REFORMS TO BOOST INCLUSIVE GROWTH IN GREECE}

ECONOMICS DEPARTMENT WORKING PAPERS No. 1298

by Christian Daude

OECD Working Papers should not be reported as representing the official views of the OECD or of its member countries. The opinions expressed and arguments employed are those of the author(s).

Authorised for publication by Robert Ford, Deputy Director, Country Studies Branch, Economics Department

All Economics Department Working Papers are available at www.oecd.org/eco/workingpapers

JT03395949

Complete document available on OLIS in its original format

This document and any map included herein are without prejudice to the status of or sovereignty over any territory, to the delimitation of international frontiers and boundaries and to the name of any territory, city or area. 
OECD Working Papers should not be reported as representing the official views of the OECD or of its member countries. The opinions expressed and arguments employed are those of the author(s).

Working Papers describe preliminary results or research in progress by the author(s) and are published to stimulate discussion on a broad range of issues on which the OECD works.

Comments on Working Papers are welcomed, and may be sent to the Economics Department, OECD, 2 Rue André-Pascal, 75775 Paris Cedex 16, France, or by e-mail to eco.contact@ oecd.org.

All Economics Department Working Papers are available at www.oecd.org/eco/workingpapers.

This document and any map included herein are without prejudice to the status of or sovereignty over any territory, to the delimitation of international frontiers and boundaries and to the name of any territory, city or area.

The statistical data for Israel are supplied by and under the responsibility of the relevant Israeli authorities. The use of such data by the OECD is without prejudice to the status of the Golan Heights, East Jerusalem and Israeli settlements in the West Bank under the terms of international law.

(C) $\operatorname{OECD}(2016)$

You can copy, download or print OECD content for your own use, and you can include excerpts from OECD publications, databases and multimedia products in your own documents, presentations, blogs, websites and teaching materials, provided that suitable acknowledgment of OECD as source and copyright owner is given. All requests for commercial use and translation rights should be submitted to rights@oecd.org 


\section{ABSTRACT/RÉSUMÉ}

\section{Structural reforms to boost inclusive growth in Greece}

This paper takes stock of the main structural reforms that Greece has undertaken since 2010, those currently proposed and that are in the process of implementation, and quantifies the medium and long-term effects on output. Special attention is given to three issues that are relevant to understanding reform dynamics in Greece: i) the short-term impact of reforms; ii) the effect of some reforms on income inequality and other socioeconomic outcomes; iii) implementation problems that might undermine the ability of structural reforms to deliver their expected outcomes. The reforms, if fully implemented, could raise output by more than $13 \%$ over the next decade. Reforms in product markets are particularly important in boosting growth. Poverty and inequality have increased despite policies to mitigate the social impacts of Greece's deep depression since 2009. Better social policies are needed to strengthen the social safety net and make growth more inclusive. Much of the burden of adjustment has been borne by labour. Labour market institutions should balance the objectives of increasing jobs, reallocating workers to where they can earn the most, and ensuring the fruits of the economic recovery are widely shared.

This working paper relates to the 2016 OECD Economic Survey of Greece

(www.oecd.org/eco/surveys/economic-survey-greece.htm).

JEL Classification: J38 ; K23 ; L43 ; O40 ; O52 : R38

Keywords: structural reforms, economic growth, inclusive growth, product markets, labour markets

$* * * * * * * * * * * * * * * * * * * * * * * * * * * * * * * *$

\section{Des réformes structurelles pour une croissance inclusive en Grèce}

Ce document a pour objet de faire le point sur les principales réformes structurelles que la Grèce a engagées depuis 2010, tant celles qui sont actuellement proposées que celles qui sont en cours de mise en œuvre, et de chiffrer les effets à moyen et à long terme de ces réformes sur la production. Une attention particulière est accordée aux trois aspects qui comptent pour appréhender la dynamique des réformes en Grèce : i) les effets à court terme des réformes ; ii) les effets de certaines réformes sur les inégalités de revenu et sur d'autres résultats socioéconomiques; iii) les difficultés de mise en œuvre qui pourraient compromettre l'obtention des résultats attendus des réformes structurelles. Si elles sont pleinement mises en ouvre, les réformes pourraient permettre d'accroître la production de plus de $13 \%$ au cours des dix prochaines années. Les réformes des marchés de produits sont particulièrement importantes pour la dynamisation de la croissance. La pauvreté et les inégalités se sont aggravées malgré les mesures prises pour atténuer les conséquences sociales de la profonde dépression dans laquelle la Grèce est plongée depuis 2009. Il faut améliorer les politiques sociales pour renforcer le système de protection sociale et rendre la croissance plus inclusive. Le fardeau de l'ajustement a reposé pour une bonne partie sur la maind'œuvre. Il conviendrait que les institutions du marché du travail parviennent à concilier les objectifs que sont la création d'emplois, le redéploiement des travailleurs vers les emplois les mieux rémunérés et un large partage des fruits de la reprise économique.

Ce Document de travail se rapporte à l'Étude économique de l'OCDE de la Grèce 2016 (www.oecd.org/fr/eco/etudes/etude-economique-grece.htm).

JEL Classification: J38 ; K23 ; L43 ; O40 ; O52 : R38

Keywords: réformes structurelles, croissance économique ; croissance inclusive ; marchés de produits ; marché de travail 


\section{Table of contents}

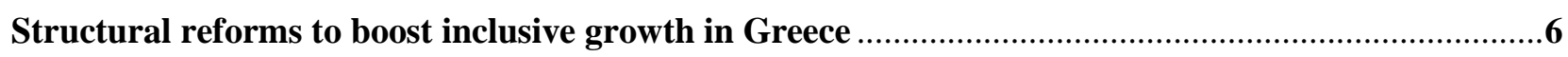

Greece has undertaken important reforms but progress has been uneven .............................................6

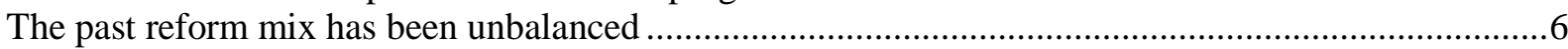

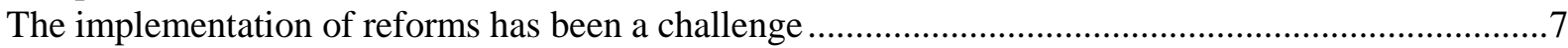

Weak and fragmented implementation has made reforms less effective ..............................................10

More ownership of the reform agenda is crucial for its long-term success..........................................10

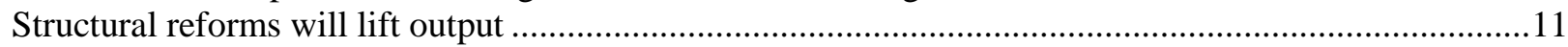

Further reforms especially in product markets are key to stronger and more inclusive growth ................13

Gains from further product market reforms are large .......................................................................13

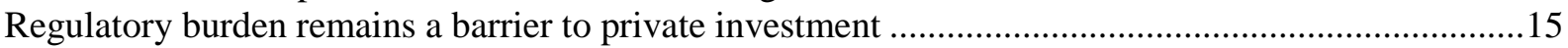

Improvements to competition policy would help eliminate existing barriers to competition .................17

More efficient bankruptcy procedures will help boost productivity ..................................................19

Implementing the new Code of Civil Procedures is important for overall reform effectiveness ...........20

The pension reform is crucial to lift employment growth in the medium run ......................................22

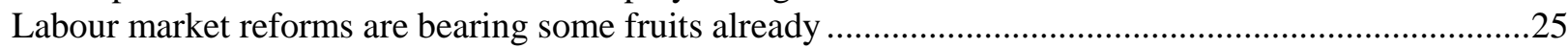

Labour market rigidities and work disincentives were high before the crisis ....................................25

The short-term costs of increased labour market flexibility have been distributed unevenly ................28

Better public employment services and vocational education and training .........................................30

Future changes in labour market institutions should balance efficiency and equity .............................31

Tax and benefit reforms should aim at supporting more inclusive growth..........................................32

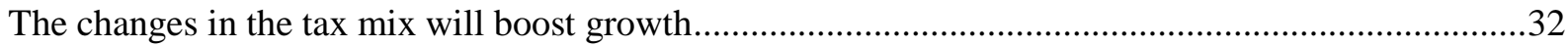

Fiscal adjustment was overall progressive, but contributed to increased poverty .................................32

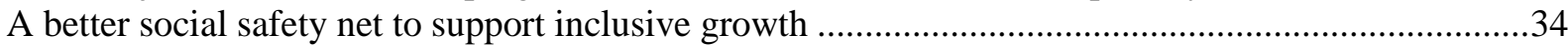

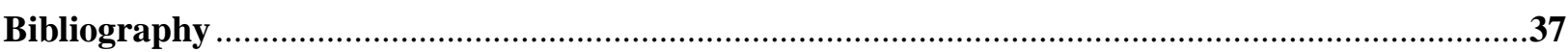

\section{Technical annex:}

Simulating the long-run impact of structural reforms on output ..............................................................

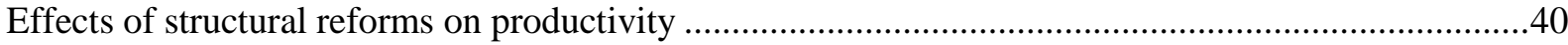

Effects on employment of labour tax wedge and pension reform .......................................................42

\section{Tables}

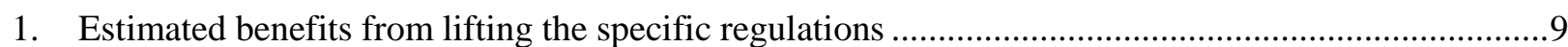

2. Estimated impact of major reforms on real GDP over a 10-year horizon .....................................12

3. The effect of individual fiscal consolidation policies on inequality ................................................33 


\section{Figures}

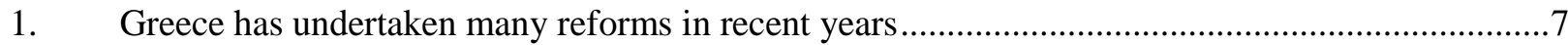

2. The depth of the recession was initially underestimated..........................................................

3. Reform implementation has been weaker in Greece than in other EU countries............................8

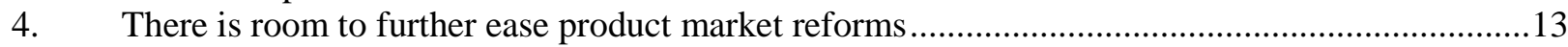

5. Network sectors are still subject to restrictive regulation in Greece.............................................14

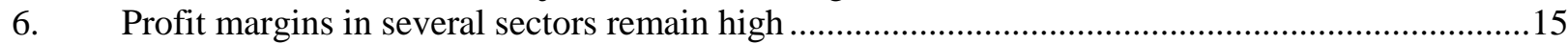

7. Regulations to open a business have eased, but other regulatory barriers remain high ................16

8. The use of regulatory impact assessments and evaluations could be expanded and improved .....17

9. Competition law and policy in Greece is relatively strong .....................................................18

10. High costs of closing a business lead to lower efficiency in the allocation of resources...............19

11. Bankruptcy procedures in Greece are time consuming and recovery rates are low......................20

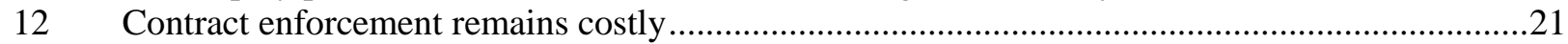

13. Pension reforms have improved the system's long-term sustainability.....................................23

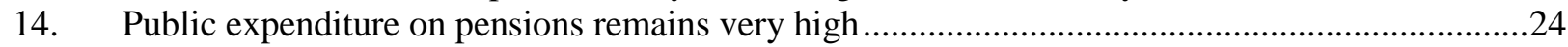

15. Labour market performance was weak before the crisis .......................................................25

16. Employment protection legislation was restrictive before recent reforms ..................................26

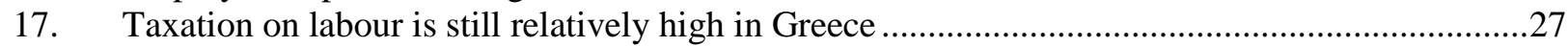

18. The tax treatment of double-income households is favourable and childcare is affordable,

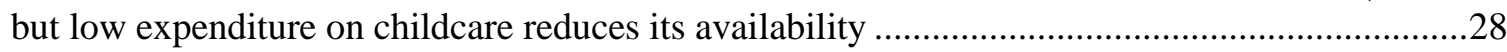

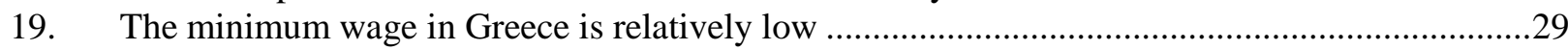

20. The effects of tax-benefit reforms and the recession on inequality and poverty ..........................33

21. The composition of social expenditures does not match the changing social challenges ..............34

22. Housing problems among the vulnerable population are widespread...........................................35

\section{Boxes}

Box 1. The OECD Competition Assessment Reviews of Greece.........................................................

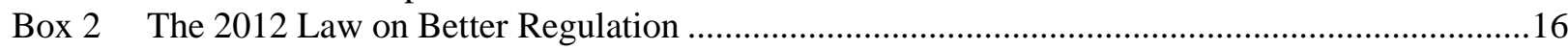

\section{Recommendations}

Recommendations on structural reforms for inclusive growth. 


\title{
Structural reforms to boost inclusive growth in Greece
}

\author{
By Christian Daude ${ }^{1}$
}

\section{Greece has undertaken important reforms but progress has been uneven}

Since 2010 Greece has embarked on a series of structural reforms to deal with its fiscal challenges and loss of competitiveness. The reform effort has been one of the strongest among OECD countries (Figure 1). Tax policy changes and expenditure cuts, particularly in pensions and the public wage bill, reduced the structural fiscal deficit by almost 14 percentage points of GDP. The size of the adjustment was around twice that of other European countries that faced sudden stops of market access. Furthermore, Greece also implemented important reforms in the labour market by decentralising the wage bargaining system, reducing the minimum wage and differentiating it for young workers and easing hiring and firing restrictions. Reforms to reduce the regulatory burden and improve the business climate were initiated in the 2012 adjustment programme, which was much later than for example with the Portuguese programme (Terzi, 2015). The reforms included reducing barriers to competition in tourism, retail, building materials, and food processing; facilitating the business licensing process in some sectors and partial opening up of restricted professions.

\section{The past reform mix has been unbalanced}

The focus on frontloaded fiscal and wage adjustments drastically reduced demand and contributed to the deep recession, as lack of product market reforms kept resources in uncompetitive activities instead of creating incentives for moving towards more efficient or new ones. The impact of fiscal multipliers in a deep recession on activity and the rise in sovereign spreads and borrowing costs were also underestimated (Blanchard and Leigh, 2013; Lewis and Pain, 2014; Figure 2). Uncertainty and delays surrounding public debt restructuring further held back investment. In the absence of strong external demand, the collapse in domestic demand overshot the necessary adjustment.

\footnotetext{
${ }^{1}$ Christian Daude is an advisor to the Chief Economist and was the senior economist on the Greece/ Colmbia desk in the OECD's Economics Department. The author would like to thank Christine De la Maisonneuve, Alain de Serres, Sean Ennis, Robert Ford, Federica Maiorano, Domna Michailidou, Álvaro Pereira, Piritta Sorsa, Ania Thiemann, and Naomitsu Yashiro. Guillaume Bousquet provided the statistical research and Anthony Bolton provided administrative assistance.
} 
Figure 1. Greece has undertaken many reforms in recent years

Reform Responsiveness Rate (average for 2011-14) ${ }^{1}$

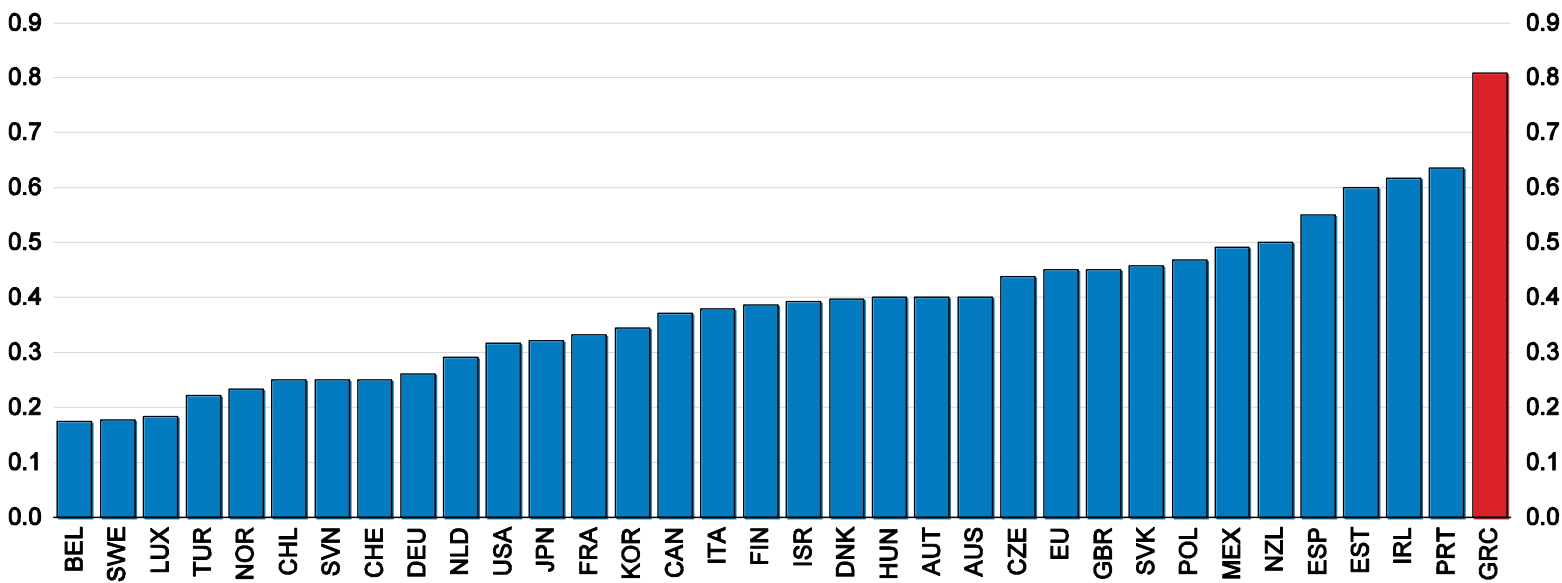

1. The reform responsiveness rate indicator is based on a scoring system in which recommendations set in the 2011 and 2013 issue of Going for Growth take a value of one if "significant" action is taken and zero if not. See Box 1.1. in OECD (2015b) for more details.

Source: OECD (2015) Economic Policy Reforms Going for Growth.

Figure 2. The depth of the recession was initially underestimated

Real GDP growth trajectory and forecasts for different vintages

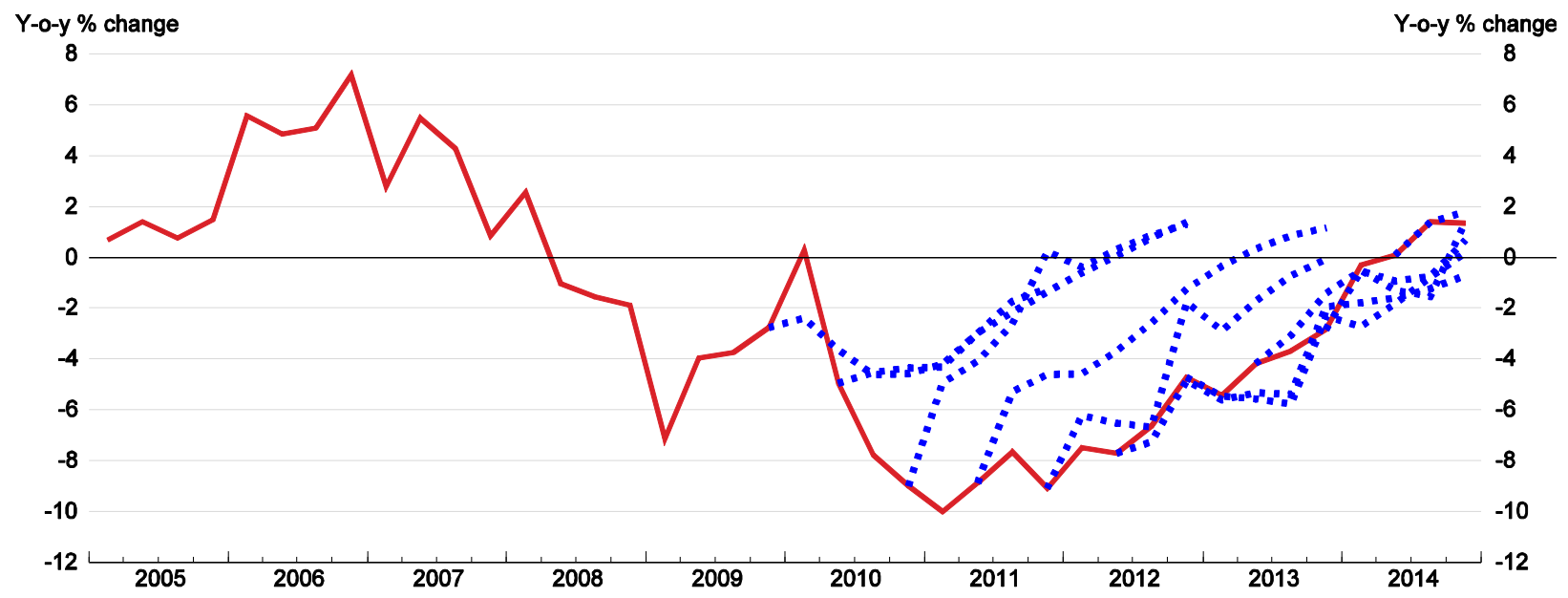

Source: OECD Economic Outlook 87 to 98 databases.

\section{The implementation of reforms has been a challenge}

The modest progress with product market reforms was due to the fact that conditionality in the first adjustment programme in 2010 was initially tied more to fiscal and labour market reforms. This implied that the incentives to advance on product market reforms were low (Terzi, 2015). The relatively weak implementation of (product market) reforms in Greece is apparent when looking at the fraction of prior actions and structural benchmarks met compared to Ireland and Portugal, which underwent a similar, although less severe, adjustment process. For example, while Portugal met over $80 \%$ of the targets on time and ended up not implementing just around $2 \%$ of them, Greece just met around $60 \%$ of its targets on time and almost one third were not met or only partially met (Figure 3). 
Figure 3. Reform implementation has been weaker in Greece than in other EU countries

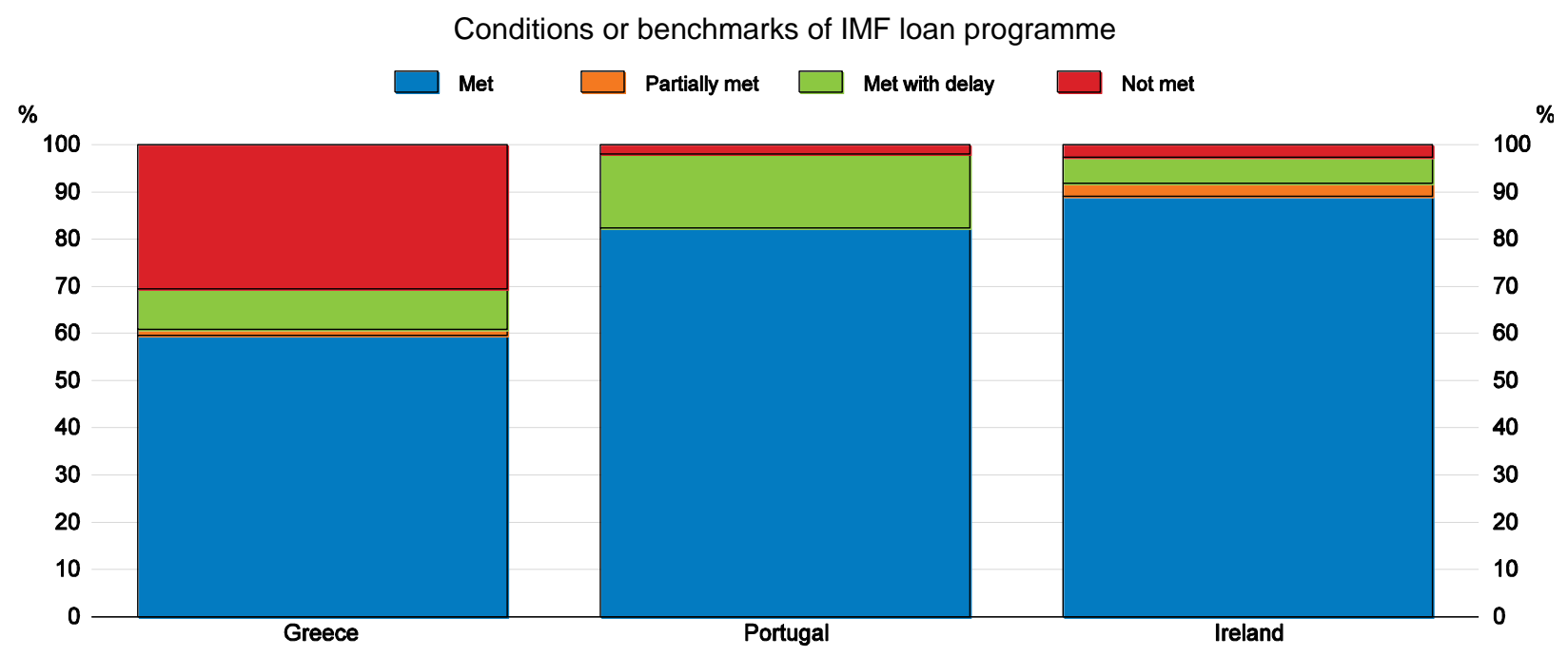

Note: The graph shows the fraction of prior actions and structural benchmarks for the IMF loans of the respective programs for all reviews corresponding to each category. Targets that were modified or waived are excluded from the analysis. For Greece, the data refer to the Stand-by Agreement of 2010 and the Extended Loan Facility of 2012.

Source: OECD calculations based on IMF MONA database

The delay in reform implementation in the second programme of 2012 was also mainly in product markets, public administration and the regulatory environment. For example, while all labour market reform targets were met, only $30 \%$ of the targets linked to private sector legal and regulatory reforms were met. Of course, this analysis has some limitations, because the economic significance of the different targets and the complexity of implementation differ. The areas of underperformance in the second programme included comprehensive issues such as investment licensing, improving bankruptcy procedures and raising the effectiveness of the judiciary, as well as opening up restricted professions and eliminating widespread nuisance taxes and third-party levies. Several of these reforms passed only in 2015 and are currently being implemented.

An important share of the product market reforms undertaken under the second adjustment programme were based on the OECD's Competition Assessment Review carried out with the national competition commission (HCC) and the Greek government in 2013. It focused on barriers to competition in food processing, retail trade, building materials and tourism, which represent around one fifth of GDP and slightly less than a third of total employment. In addition, some horizontal restrictions such as advertising taxes, transport, licensing and urban planning restrictions were also detected, but only partially removed. Although it is difficult to assess the impact of lifting these restrictions, OECD estimates show sizeable effects through higher turnover and lower prices for consumers of these reforms (Box 1). At the end of 2014, the IMF estimated that around $72 \%$ of the recommendations of the first competition assessment were implemented (IMF, 2014). Furthermore, several of the recommendations that were not implemented or only partially implemented were those with the largest estimated economic impact, such as Sunday trading or eliminating advertising fees (Box 1). 


\section{Box 1. The OECD Competition Assessment Reviews of Greece}

Competition assessment is a powerful tool to help policy makers improve the workings of the economy by identifying and lifting regulations that restrict competition in product markets, service and network sectors, and rules governing public tenders. The OECD's "Competition Assessment Toolkit" supports government efforts to improve regulatory impact assessment to eliminate barriers to competition. It provides a straightforward method for identifying unnecessary regulatory restraints on market activities and developing alternative, less restrictive measures that still achieve government policy objectives. One of the main elements of the Competition Assessments is a "Competition Checklist" that asks a series of simple questions to screen laws and regulations that have the potential to unnecessarily restrain competition, which helps focus limited government resources on the areas where competition assessment is most needed. The assessment is designed for use by government officials that draft and review regulation, whether at national or sub-national level. It is not particularly addressed to competition experts. The reason for designing the materials with this flexibility is that restrictions on competition can be implemented at many different levels of government and competition assessment can be helpful at all these levels.

In 2013 and 2014, the OECD, in collaboration with the Hellenic Competition Commission (HCC), carried out a project to identify and assess anti-competitive regulation and legislation, based on the OECD's Competition Assessment methodology. The findings were used to pinpoint the necessary measures to lift these restrictions to stimulate the emergence of a more competitive environment for Greek and foreign businesses to operate in. The project's central aim was to improve competition in the sectors of the Greek economy under scrutiny. In 2013, four sectors were analysed: food processing, retail trade, building materials and tourism. These sectors had a combined turnover of EUR 44 billion in 2011, equivalent to $21 \%$ of GDP, and represented almost 1.5 million jobs or $26 \%$ of total employment in Greece in 2011 . Lifting the restrictions to competition in these sectors is likely to have a significant positive economic impact, both short term and long term. The OECD identified 555 regulatory restrictions and made 329 individual recommendations on specific legal provisions that should be amended or repealed. Overall, the 2013 OECD study found, a total of EUR 5.2 billion (2.5 of GDP) in economic benefits from lifting the 329 restrictions identified (Table 1).

Table 1. Estimated benefits from lifting the specific regulations

\begin{tabular}{|c|c|c|c|c|}
\hline Issue & $\begin{array}{l}\text { Annual Benefit } \\
\text { Millions of EUR }\end{array}$ & $\begin{array}{l}\text { Number of } \\
\text { provisions } \\
\text { affected }\end{array}$ & $\begin{array}{c}\text { Value to } \\
\text { economy, } \\
\text { Millions of } \\
\text { EUR }\end{array}$ & Implementation \\
\hline "Fresh" milk & 33 (consumer benefit/year) & 2 & 33 & $\begin{array}{c}\text { Partially } \\
\text { implemented }\end{array}$ \\
\hline Levy on flour & 8-11 (value of levy/year) & 1 & 8 & Implemented \\
\hline Sunday trading & $\begin{array}{c}2500 \text { (annual expenditure), } \\
\text { plus } 30000 \text { new jobs }\end{array}$ & 3 & 2500 & Not implemented \\
\hline Sales and discounts & 740 (annual turnover) & 9 & 740 & Implemented \\
\hline $\begin{array}{l}\text { Over the Counter } \\
\text { pharmaceuticals }\end{array}$ & 102 (consumer benefit/year) & 23 & 102 & $\begin{array}{c}\text { Partially } \\
\text { implemented }\end{array}$ \\
\hline Marinas & 2.3 (annual turnover) & 10 & 2 & Implemented \\
\hline Cruise business & 65 (annual turnover) & 4 & 65 & Implemented \\
\hline Advertising & 1800 (consumer benefit/year) & 14 & 1800 & Not implemented \\
\hline
\end{tabular}

Source: OECD (2014a), OECD Competition Assessment Reviews GREECE

During 2014, a second review of four manufacturing sub-sectors was carried out: beverages; textiles, wearing apparel and leather; machinery and equipment, and coke and refined petroleum products. Out of the 88 OECD recommendations on specific provisions to be amended or abolished, some concerned the implementation of stockholding obligations for petroleum producers, wholesalers and importers. The implementation of these recommendations is part of the new agreement with the institutions. Around 40 recommendations of this second assessment have been implemented since August 2015.

There is no reason to suppose that these problems are confined to the sectors that have been studied. Indeed, the analysis so far has revealed the existence of overlapping or adjacent regulation that appeared equally important, but was outside the scope of the projects. 


\section{Weak and fragmented implementation has made reforms less effective}

Lack of full implementation of product market reforms has often implied that substantive changes in policies have had little economic impact, but potentially high political costs. For example, truck licensing has historically been among the most restrictive in the OECD. From the mid-1970s no licenses had been issued, such that the only way to obtain a license was by buying it in the secondary market at high prices (Katsoulacos, et al., 2015). Despite strikes and strong resistance a deregulation process started in 2010. Law 3887/2010 and subsequent laws (4038/2012 and 4093/2012) further liberalised a significant part of the truck licensing process. However, few new licenses have been issued. While weak domestic demand and lack of finance is an important factor in explaining the low rate of new entry, other remaining restrictions play a role. The issuance of a permanent license for a truck was tied to the gross profits of the applicant. There were also limits to the number of licenses. These restrictions were already detected in OECD competition assessment in 2013 (OECD, 2014a), but they were only lifted in August 2015. Overall, this implies that product market restrictions were lifted only gradually and that regulations are still among the most restrictive among OECD economies.

In many cases, the effectiveness of reforms has been undermined by lack of a coordinated approach to lifting bottlenecks in related areas. For example, Greece has undertaken important reforms in creating a one-stop shop to deal with licenses to open and register a new business, including a common electronic platform that interconnects several government agencies, a reduction in registration fees and abolishing minimum capital requirements for limited liability firms. This led to a significant reduction in the cost of opening a firm in Greece. For example, while in 2011 it took 15 procedures to open a business and around 20 days, in 2015 only 5 procedures were required and it would take only 13 days (World Bank, 2016). However, procedures and licenses needed to start operating, such as registration of property, dealing with construction permits, getting electricity, and health inspections have only changed marginally. Therefore, despite progress in easing the burden of entry, the regulatory burden for operating a business in Greece continues to be heavy. A more co-ordinated approach to reform would help detecting complementarities across areas of reform. To address this issue, several countries in the OECD have created cross-cutting commissions at the centre of government or agencies to coordinate policy implementation between different ministries and levels of government.

\section{More ownership of the reform agenda is crucial for its long-term success}

Implementing a substantial amount of reforms over a short time period, in a context of depressed aggregate demand and with a relatively weak public administration is a challenging task. However, the economic situation is turning, fiscal consolidation needs are more moderate and external conditions are more supportive. The $2015 \mathrm{MoU}$ also includes several actions related to alleviating the social crisis and building institutions for more inclusive growth, mitigating the impact on reforms on affected groups. Fully implementing the reforms agreed with the institutions would allow reaping their benefits faster.

Acceptance of reforms may also be facilitated by tackling more sectors with concentrated economic power. Most sectors in the first OECD Competition Assessment were dominated by SMEs. Several of the current priority sectors for reducing barriers to competition are oligopolistic with influential interest groups. Fighting tax evasion would also not only produce more revenues to balance budgets and boost social expenditure, but improve perceptions of the fairness of reforms. Under these conditions, delivering on the reform programme could boost confidence and allow more front-loading of the benefits of reforms than in the recent past. A positive development is that the government now has a clear mandate to implement the reform agenda, which is generally a precondition for successful implementation (OECD, 2010a). This would also be essential to build political support for more reforms needed to modernise the Greek economy, such as reforming the public administration and the judiciary, which will require a sustained effort and political support over time. 
A transparent and clear communication strategy of the expected benefits of reforms to the general public, especially those who would most benefit from them, would help in building support for the reform programme. Particularly in the Greek case, many of the past reforms have been framed as externally imposed, with an emphasis on the short-term costs rather than the medium-term rationale of modernising the Greek economy or the costs of inaction (OECD, 2010a). For example, in the case of removing barriers to competition in a particular sector, communication should shift from emphasising the cost for incumbent firms towards the benefits for the consumer and job creation.

The experience of other OECD countries shows that successful reforms are generally based on a good diagnostic and quantification of these benefits (OECD, 2010a). Therefore, it is important to build more analytical capacity in fields such as tax policy, efficiency of government expenditures and pensions to quantify the growth, employment and distributional effects of policies. Designing policies that are based on an ex-ante evidence based analysis and include monitoring and evaluation stages in their conception improve effectiveness. Moreover, properly designed policies enhance stability as frequent changes in polices create uncertainty for consumers and firms. Some positive steps in this direction are already happening, as shown by the proposed pension reform that goes beyond changing the pension system to achieve fiscal targets under the MoU and aims at reducing broader inequities and inefficiencies in the Greek pension system by abolishing special regimes and introducing a basic pension.

\section{Structural reforms will lift output}

The reforms that have been undertaken in recent years and the reforms that the government is currently carrying out, if fully implemented, will raise output beyond levels implied by the cyclical recovery of the economy. OECD estimates show that product and labour market reforms that have been undertaken already, combined with several of the reforms planned within the $2015 \mathrm{MoU}$, could boost output significantly over the next decade. Coupled with the cyclical recovery this would return Greece to its pre-crisis GDP per capita level. Product market reforms, the pension reform, tax reform and the changes to the legal bankruptcy framework would bring the most significant impact on output (Table 2).

These estimates might represent a lower bound as some reforms or aspects of reforms are not quantified, because this cannot be done in the current framework. For example, the quantification of the August 2015 changes in bankruptcy procedures cover the changes in the allocative efficiency and ability to catch up to the technology frontier (Saia, et al., 2015). However, the estimates do not take into account the effects of the reforms on resolving the large non-performing loans in the banking system, which would free resources to more productive activities and enable banks to start extending more credit. Similarly, the implementation of the recommendations of the second OECD Competition Assessment, currently in process, and the potential reduction in restrictions to competition in construction, wholesale or further deregulation of network sectors is not assessed at this stage. Similarly, the employment effects and the potential impact of more efficient reallocation of resources from changing the wage bargaining system or the minimum wage are not assessed, given that the framework used only quantifies changes in the OECD Employment Protection Legislation indicator (see Annex). Their effect could potentially be sizeable, as shown by other studies of countries with similar challenges (e.g. see OECD (2013a) for Spain). 
There are some limitations which imply that the estimates are subject to uncertainty. First, the estimates assume that legislated reforms are implemented at the OECD's average quality, which might be optimistic given the delays and problems with reform implementation in the past. Second, they do not take into account short-term interactions with aggregate demand or with reforms in other areas. In particular, this might lead to an overestimation, at least in the short run, of some of the employment growth effects. For example, concerning the pension reform, the estimates implicitly assume that people will chose to work for more years and actually find a job, which might prove difficult. The impact on GDP and employment of some of the main recent reforms are discussed in more detail in Table 2.

Table 2. Estimated impact of major reforms on real GDP over a 10-year horizon ${ }^{1}$

\begin{tabular}{|c|c|c|c|}
\hline Reform & GDP & $\begin{array}{l}\text { Via Employment } \\
\text { growth }\end{array}$ & $\begin{array}{c}\text { Via } \\
\text { Productivity } \\
\text { growth }\end{array}$ \\
\hline \multicolumn{4}{|c|}{ Reforms implemented 2010-2014 } \\
\hline Product Market Reforms & 3.4 & & 3.4 \\
\hline Product market reform between $2010-13$ & 2.9 & & 2.9 \\
\hline Product market reform in 2013-14 & 0.5 & & 0.5 \\
\hline Labour Market Reforms ${ }^{2}$ & 0.9 & 0.6 & 0.3 \\
\hline Employment Protection Legislation reform in $2010-13$ & 0.3 & & 0.3 \\
\hline Pension reform & 0.6 & 0.6 & \\
\hline Tax reform & 1.3 & & 1.3 \\
\hline Total implemented reforms & 5.6 & 0.6 & 5.0 \\
\hline \multicolumn{4}{|c|}{ Reforms currently being implemented or planned in the MoU } \\
\hline Product Market reforms & 4.4 & & 4.4 \\
\hline $\begin{array}{l}\text { Network industries reform (electricity, gas, rail road and } \\
\text { transport) }\end{array}$ & 2.3 & & 2.3 \\
\hline Other product market reforms ${ }^{3}$ & 2.1 & & 2.1 \\
\hline Labour Market reforms & 2.4 & & \\
\hline Pension reform & 2.2 & 2.2 & \\
\hline Employment protection legislation & 0.2 & & 0.2 \\
\hline Tax reform & 0.8 & & 0.8 \\
\hline Bankruptcy reform & 0.2 & & 0.2 \\
\hline Total planned reforms & 7.8 & 2.2 & 5.6 \\
\hline Total implemented and planned reforms & 13.4 & 2.8 & 10.6 \\
\hline
\end{tabular}

1. See Annex for the methodology used to estimate the impact of reforms.

2. Reforms to the wage bargaining system are not assessed in this exercise.

3. Includes reforms to reduce administrative burden, opening closed professions, trade facilitation and investment licensing.

Source: OECD calculations. 


\section{Further reforms especially in product markets are key to stronger and more inclusive growth}

\section{Gains from further product market reforms are large}

Although reforms so far have moved Greece close the OECD average in restrictiveness of product markets, additional reforms could substantially boost growth further (Figure 4). Product market reforms are crucial to increasing productivity and getting investment started again. Sectoral indicators show that there is significant room for improving regulations especially in network sectors. In particular, in rail and road transport, as well as electricity and gas, a combination of public ownership, barriers to entry and a significant vertical integration leads to relatively high costs that undermine the competitiveness of the rest of the economy (Figure 5). The gains for firms, in particular in export activities would be substantial for moving closer to OECD best practices. Therefore, the plans for deregulation and privatisations in these sectors should be a priority. Bringing regulation in line with the OECD average, which would be the outcome if the $2015 \mathrm{MoU}$ actions on network sectors are fully implemented, would raise output by more than 2 percentage points in the next decade.

Figure 4. There is room to further ease product market regulations

Index scale from 0 - 6 (least to most restrictive)

2008

3.0

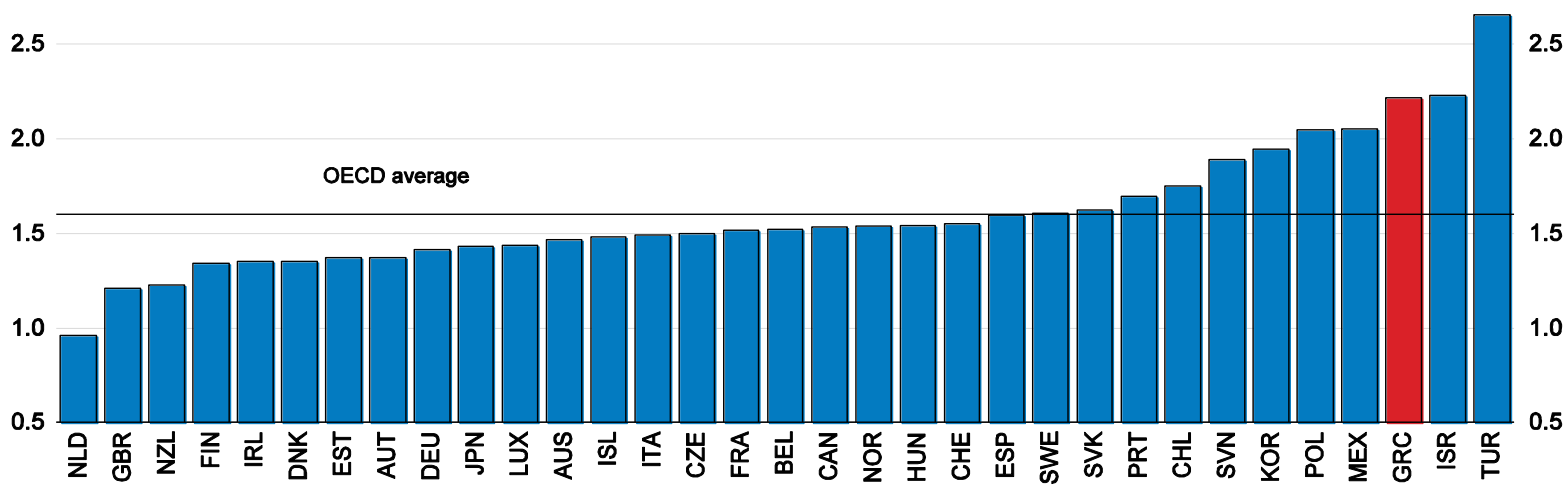

2013

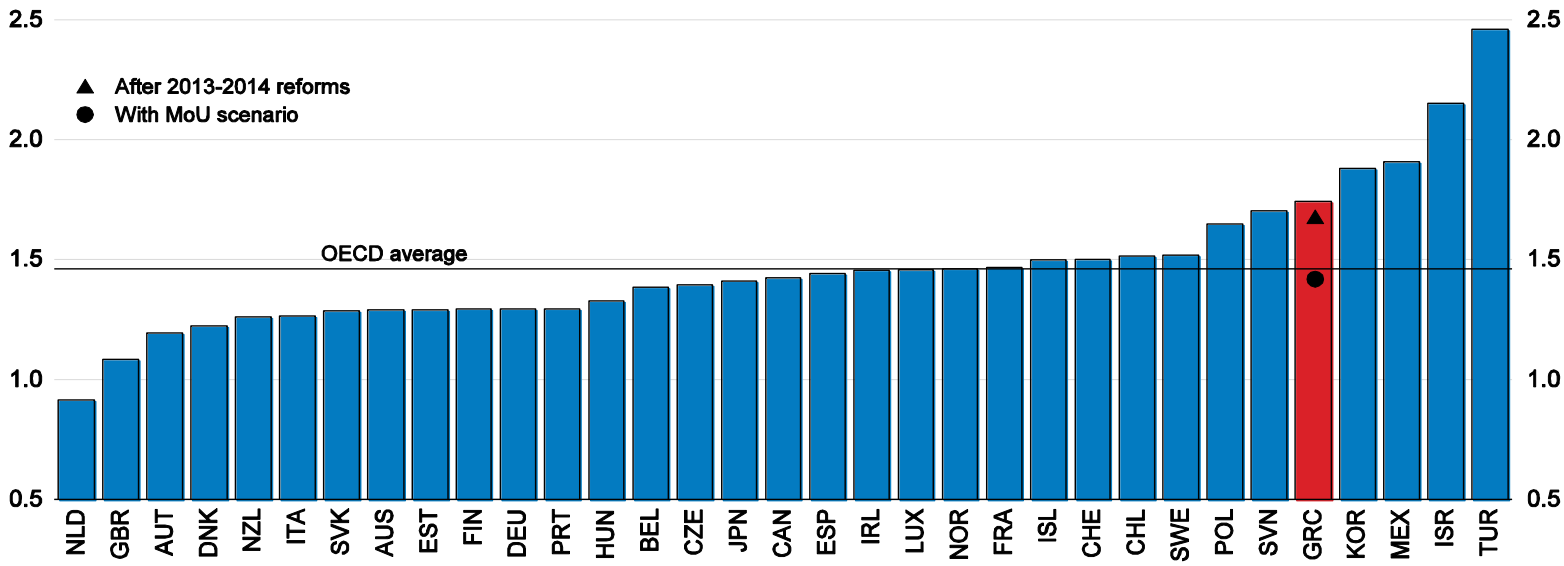

Source: OECD (2015) Product Market Regulation database. 
Figure 5. Network sectors are still subject to restrictive regulation in Greece

Index scale of 0-6 from least to most restrictive, 2013

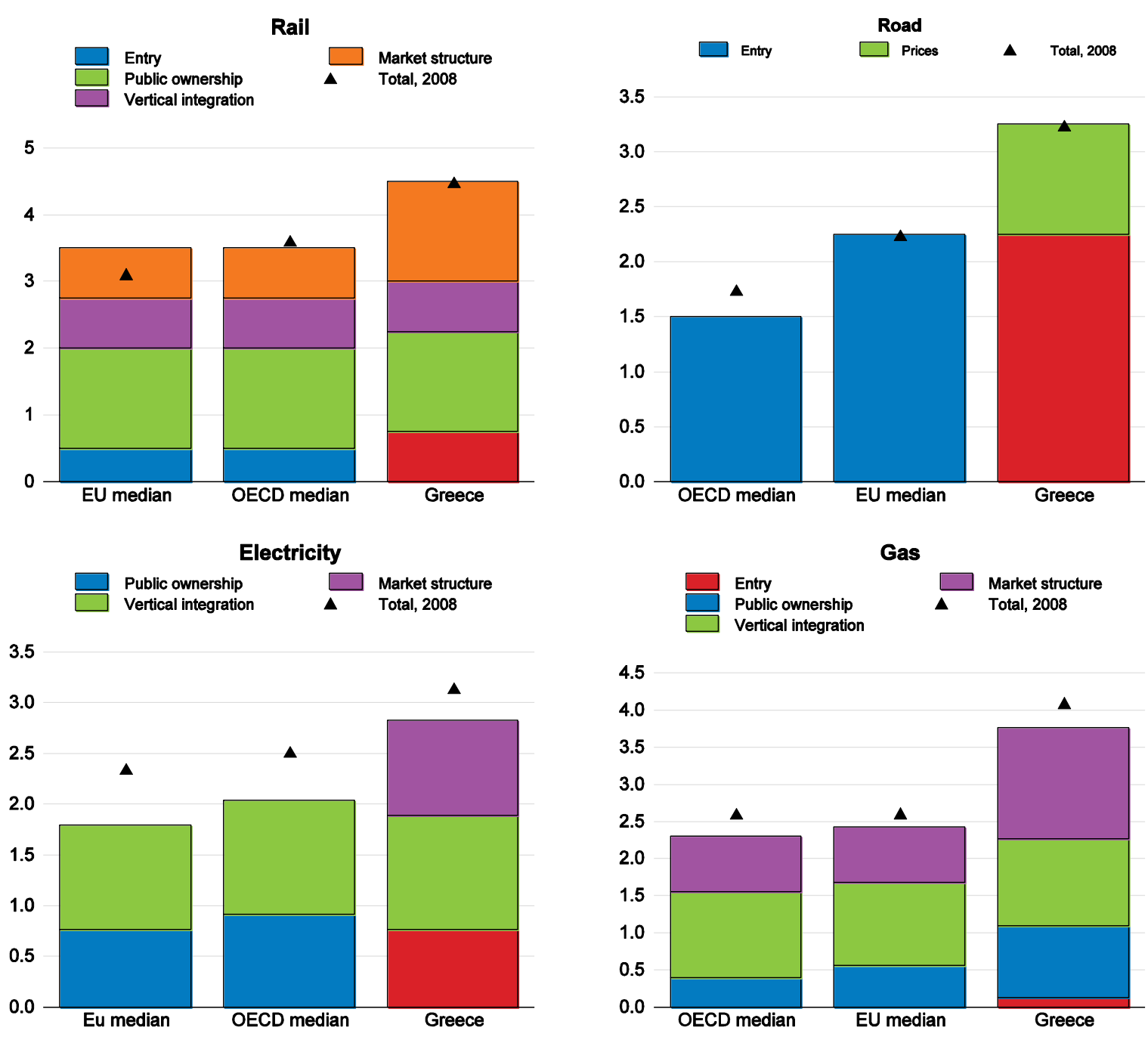

Source: OECD (2015) Product Market Regulation database

A number of other sectors with high profit margins compared to the EU average could also be targeted. Many of these sectors, especially those with the highest profit margins, have been part of the competition assessments carried out with the OECD in the recent past (Figure 6). Other sectors included in the $2015 \mathrm{MoU}$, such as construction and remaining manufacturing activities also appear with profit margins above the EU average. Some of these sectors might present a higher profit margin because of the prevalence of small enterprises, such that the remunerations of the owners of SMEs are part of profits. However, the differences in many sectors remain large when compared to countries with similar levels of self-employment. Specific barriers to competition will be examined in 2016 jointly with the technical assistance of the OECD. Therefore, while reforms in these sectors could contribute to productivity growth, they cannot be quantified currently as it is not clear what part of the profit margins are due to barriers to competition and how these could be removed. 


\section{Figure 6. Profit margins in several sectors remain high}

Difference with respect to the EU average in net profit margins

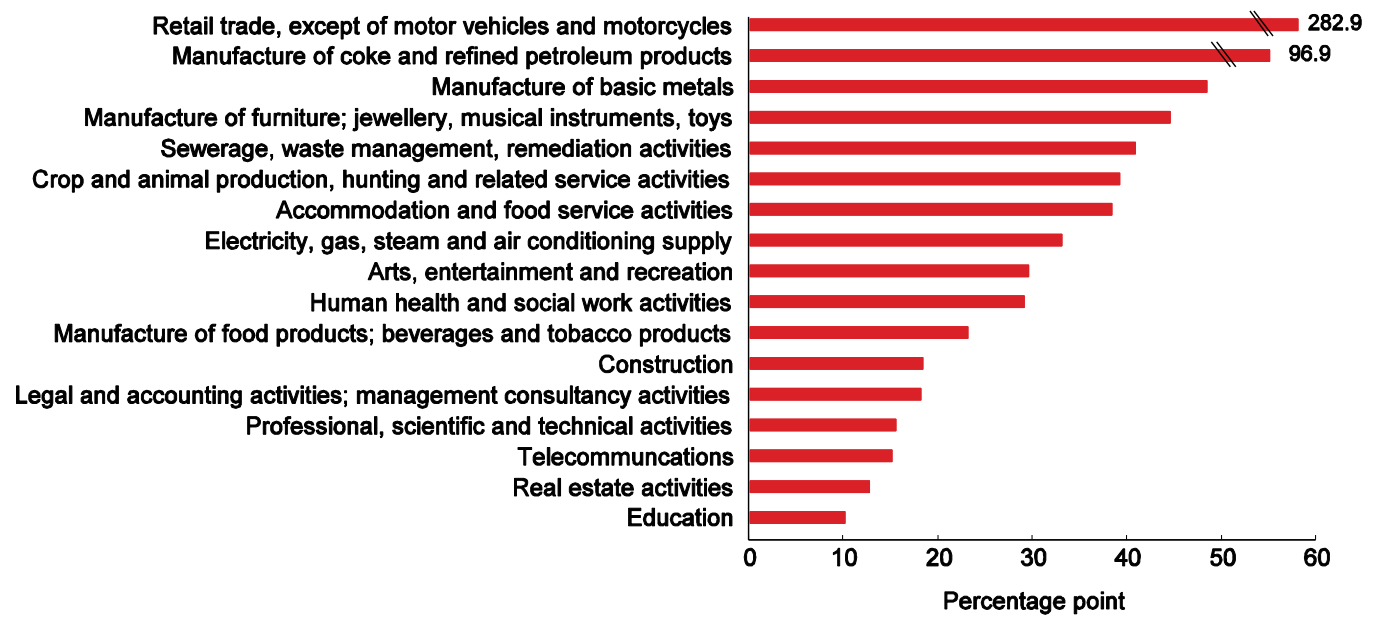

Note: The difference is based on a 2012-2014 average. Only sectors whose value added represents at least $1 \%$ of total value added are considered. In Greece, the large share of self-employed can bias the profit numbers as they may include other remunerations.

Source: OECD calculations based on Eurostat data.

\section{Regulatory burden remains a barrier to private investment}

Greece has undertaken efforts to reduce the costs of doing business, but results so far are limited, as discussed above. Licensing procedures and regulations to operate a business continue to be relatively burdensome. In the areas of getting a construction permit or registering property, which are important for investments - for example in retail, tourism and logistics - Greece continues to perform badly, despite some limited reform to accelerate the decision process at the local-government level (Figure 7).

The proper implementation of the one-stop shop for dealing with all licenses and permits for operating a business and of the 2012 Law on Better Regulation would allow a more systemic approach to reducing administrative burden (see Box 2). Several sectorial studies have detected regulations that raise the cost of doing business or create barriers to entry (OECD, 2014b). However, instead of relying on ad-hoc assessment, a more systematic use of regulatory impact assessments (RIA) would help identify the effects of regulation on business and citizens before they are implemented. In particular, for secondary legislation and regulations and ex-post RIA, the gap in using these instruments is significant (Figure 8). In several OECD countries, the effectiveness of RIA has been increased by introducing complementary rules. For example, sunset clauses to regulations that provide for the automatic review or expiry of laws or rules like in the United Kingdom's "one-in, two-out" that create incentives to internalise and evaluate the cost of introducing new regulations. 
Figure 7. Regulations to open a business have eased, but other regulatory barriers remain high

\section{Procedures needed to start a business}

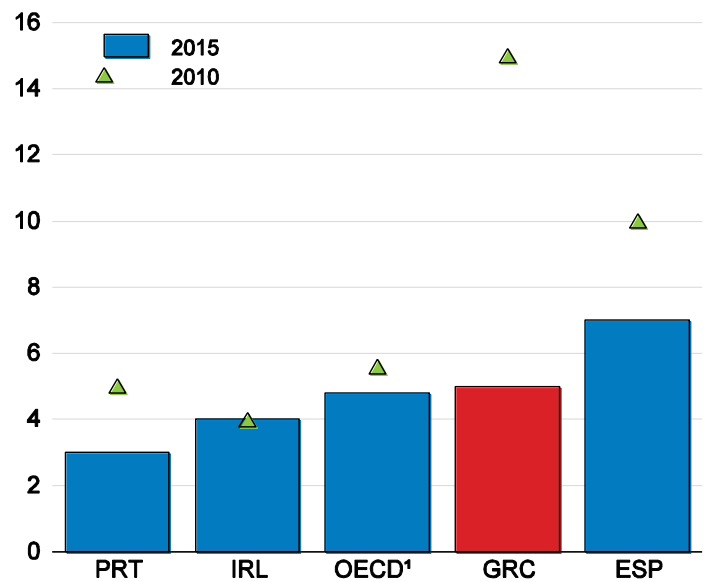

Procedures needed to get electricity

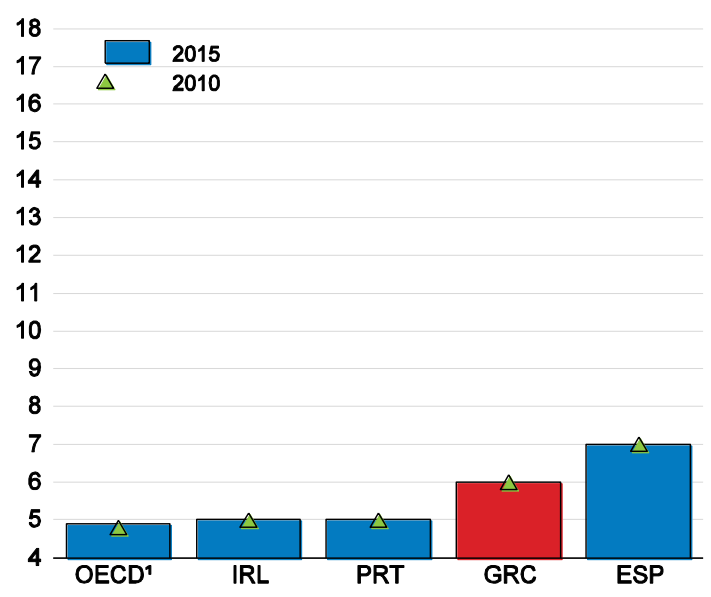

\section{Procedures needed to get a construction permit}

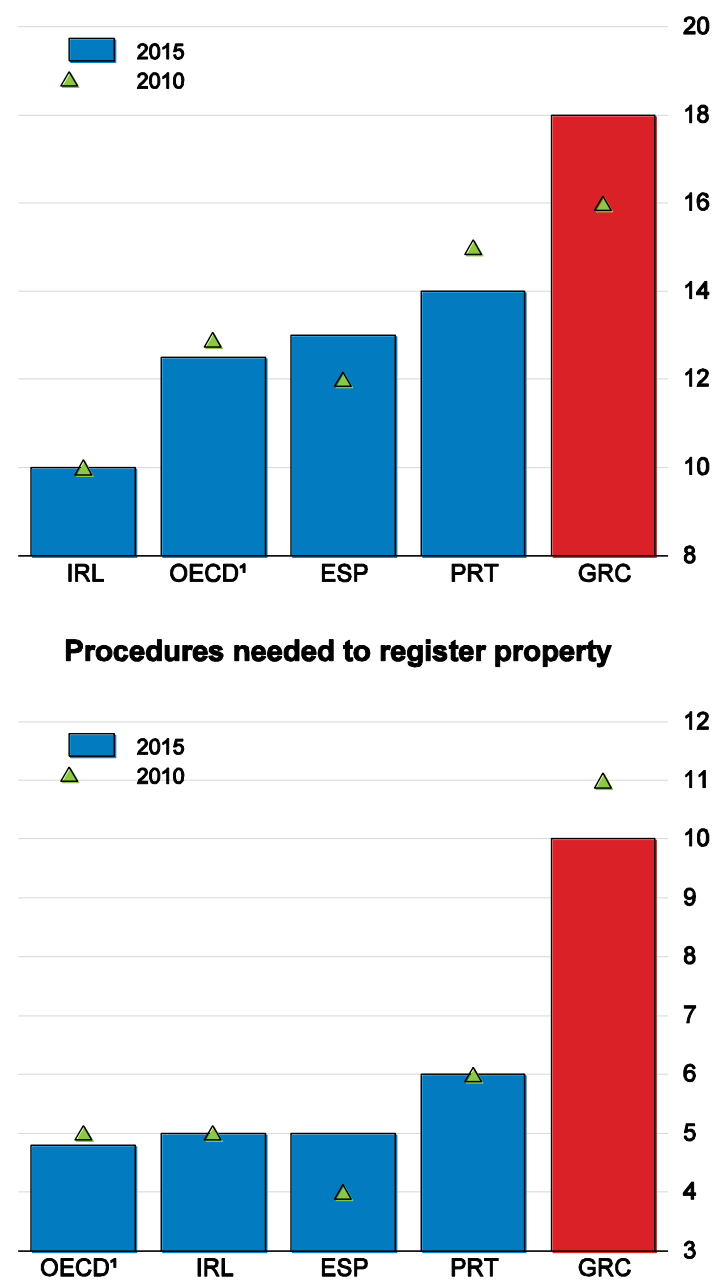

1. OECD is a simple average of all OECD countries data except the United States.

Source: World Bank (2015a), Doing Business database.

\section{Box 2 The 2012 Law on Better Regulation}

The law on Better Regulation adopted in February 2012 states the principles of Better Regulation including: necessity; proportionality; effectiveness and efficiency of the regulation; transparency; accessibility and the avoidance of controversial regulations, and mandates the regulator to comply with these principles. In addition to ex ante RIA for every legislative draft or amendment to existing regulations, it requires an ex post impact assessment of the regulation's cost, benefit and impacts. This must take place after three years and no later than five years after implementation. It also defines steps and deadlines of public consultation procedures for new legislation, describes procedures for the transposition of the EU law and reinforces the institutional framework for regulatory policy through the establishment of the Office for the Support of Better Regulation in the General Secretariat of the government.

Source : OECD (2015b), Regulatory Policy Outlook 2015. 
Figure 8. The use of regulatory impact assessments and evaluations could be expanded and improved
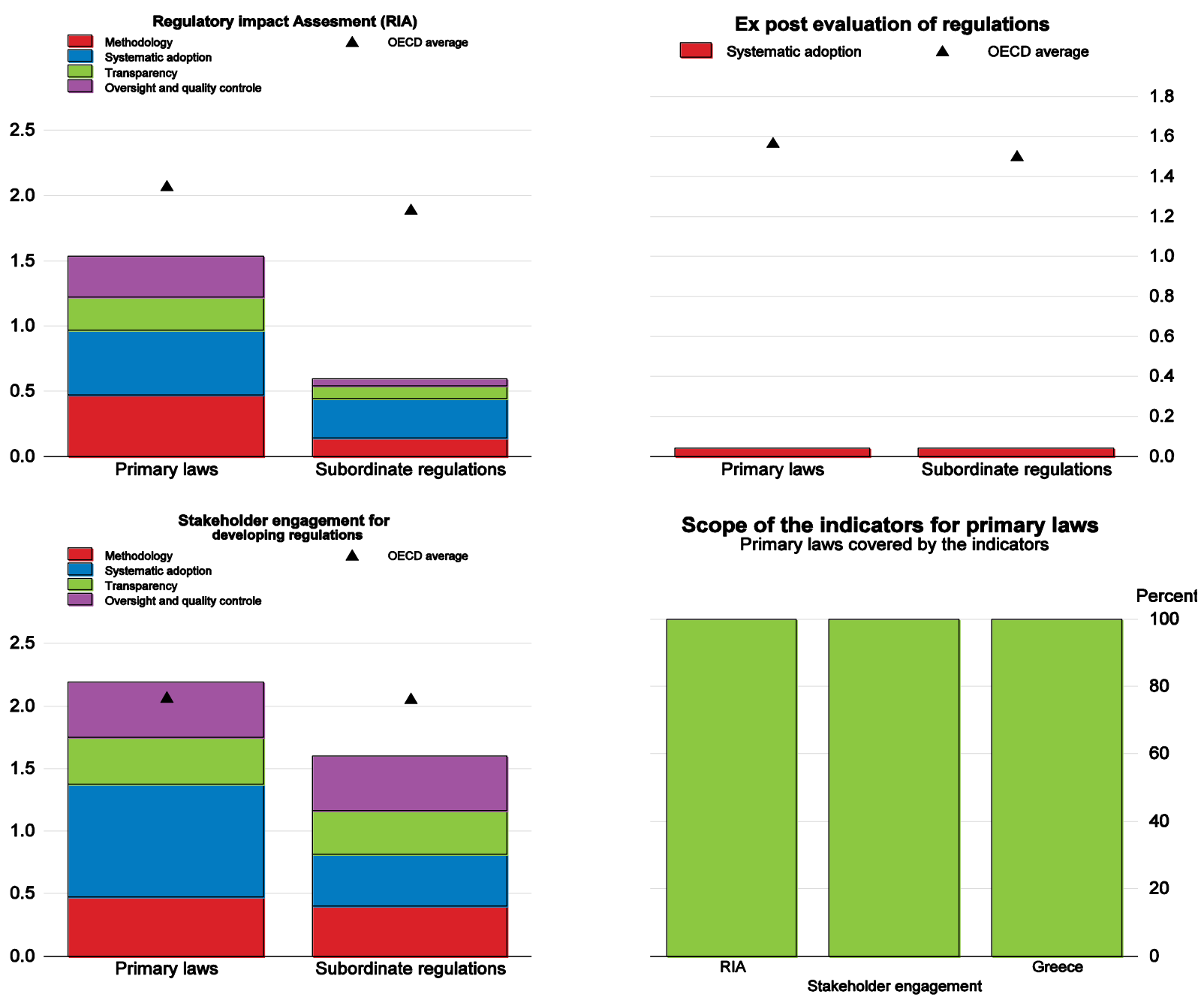

1. The figures display the aggregated scores from all four categories giving the total composite score for each indicator. The maximum score for each category is one and the maximum score for each aggregated indicator is four.

2. Although members of parliament can initiate primary laws in theory in Greece, in practice all primary laws are initiated by the executive. Hence, the information presented in the indicators for primary laws on RIA, stakeholder engagement and ex post evaluation covers processes in place for all national primary laws in Greece.

Source: OECD (2014) Regulatory Indicators Survey results, www.oecd.org/gov/regulatory-policy/measuring-regulatoryperformance.htm.

\section{Improvements to competition policy would help eliminate existing barriers to competition}

Recent changes in the legal framework of competition policy and the HCC have brought the legal framework close to OECD best practices (Figure 9). European competition law applies, complemented in 2012 by a domestic competition law which has strengthened the legal framework by giving new powers and greater independence to the HCC and creating stronger penalties. The HCC itself has been reformed and has vigorously enforced the law. It now has the ability to assess and object to new legislation that might be anti-competitive and it has been closely involved in reform, either working alone (e.g. on liberalisation of professional services), or with the OECD (e.g. on retail and manufacturing). A clear policy based on a point system for case prioritisation has been instrumental to focus the HCC's efforts on more relevant cases. 
More resources for advocacy work would help the HCC to expand its work outside the area of law enforcement. There is room for moving closer to best practices by working more on market studies to assess regulations or planned legislation that are barriers to competition (Figure 9). The plan included in the $2015 \mathrm{MoU}$ of increasing the HCC's advocacy unit by twelve additional staff posts is welcome in this regard. As shown by the two OECD competition assessments, there are many obstructions to competition in the Greek economy. Restrictions have often been designed to achieve an understandable purpose (e.g. preventing evasion of excise duties), but generally introduced without assessment of the costs of restricting competition and consequently have anti-competitive effects. Greece does not need large changes in its legal regulatory framework, but rather an improvement in its ability to eliminate unnecessary restrictions on competition.

\section{Figure 9. Competition law and policy in Greece is relatively strong} Index from 0 to 6 , from most to least conducive to competition

Scope of action
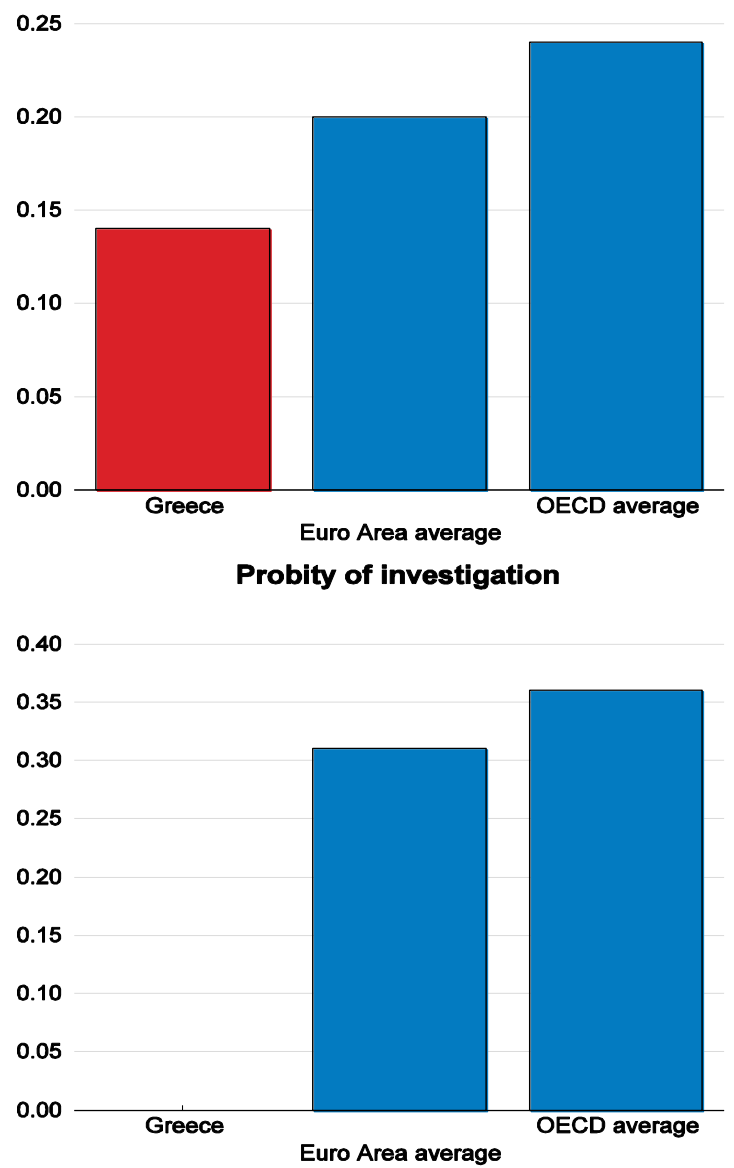

Policy on anticompetitive behaviours
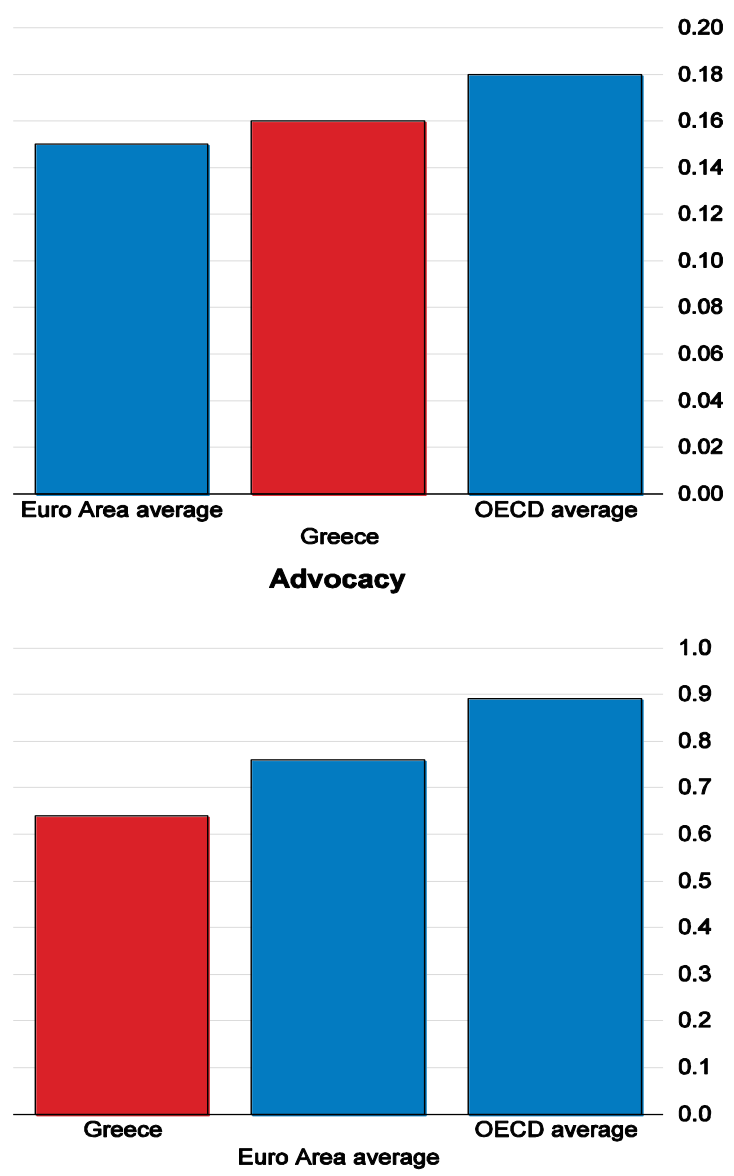

Source: Alemani, E., et al. (2013), "New Indicators of Competition Law and Policy in 2013 for OECD and non-OECD Countries", OECD Economics Department Working Papers, No. 1104, OECD publishing doi : 10.1787/5k3ttg4r657h-en.

Greece would also profit from strengthening the judicial process related to competition by creating specialised appeal courts and training judges. Currently decisions tend to be taken on a formalistic assessment rather than the impact on social welfare, which often leads to decisions that reduce consumer welfare (Katsoulacos et al., 2015). In this regard, including economists or judges with specific training in economics and competition in the bodies dealing with competition cases can be useful. 


\section{More efficient bankruptcy procedures will help boost productivity}

Bankruptcy regulation is key for the reallocation of resources in the economy. While regulatory burden and barriers to competition mainly affect productivity by reducing entry of new firms, high costs and burdensome regulations to resolve corporate bankruptcy leads to lowering the exit of non-profitable firms. This reduces productivity by keeping labour and capital locked into low productivity firms (Figure 10). It also reduces the speed at which the economy absorbs technological progress at the frontier (Saia et al., 2015). Greece has historically underperformed in all relevant dimensions of an efficient bankruptcy regulation: costs, time involved in the procedures and the outcome in terms of the recovery rates, despite important changes in bankruptcy regulation in 2007 and some improvements in recent times, such as the elimination of a cumbersome conciliation procedure in 2013 (Figure 11).

Changes to the Bankruptcy Code introduced in August 2015 (Law 4336/2015) will improve the efficiency of bankruptcy procedures. Among several changes, two stand out. First, the new law increases the creditor rights of banks vis-à-vis the Greek state. This creates incentives for banks and creditors in general to use legal procedures to take debtors to bankruptcy courts and/or liquidate assets that are non-performing. In the past, the public sector had a more privileged creditor position regarding unpaid VAT and other taxes (including fees and sanctions) and social security claims compared to other creditors, in particular banks. Combined with a long and uncertain judicial procedure during which debtors could still get legal protection enabling them to potentially divert all remaining valuable assets, incentives to proceed with bankruptcy by creditors were low. This was reflected by the long periods required to resolve bankruptcy cases and the low recovery rates (Figure 11). Second, important deadlines have been shortened, such as the notice period of creditors, the period for claim confirmations, the time to raise objections to the bankruptcy court, as well as the period this court has to issue a ruling on these objections. The changes introduced in August 2015 will allow for more efficient exit, separating inviable firms from those financially distressed but viable, and help boost productivity.

Figure 10. High costs of closing a business lead to lower efficiency in the allocation of resources

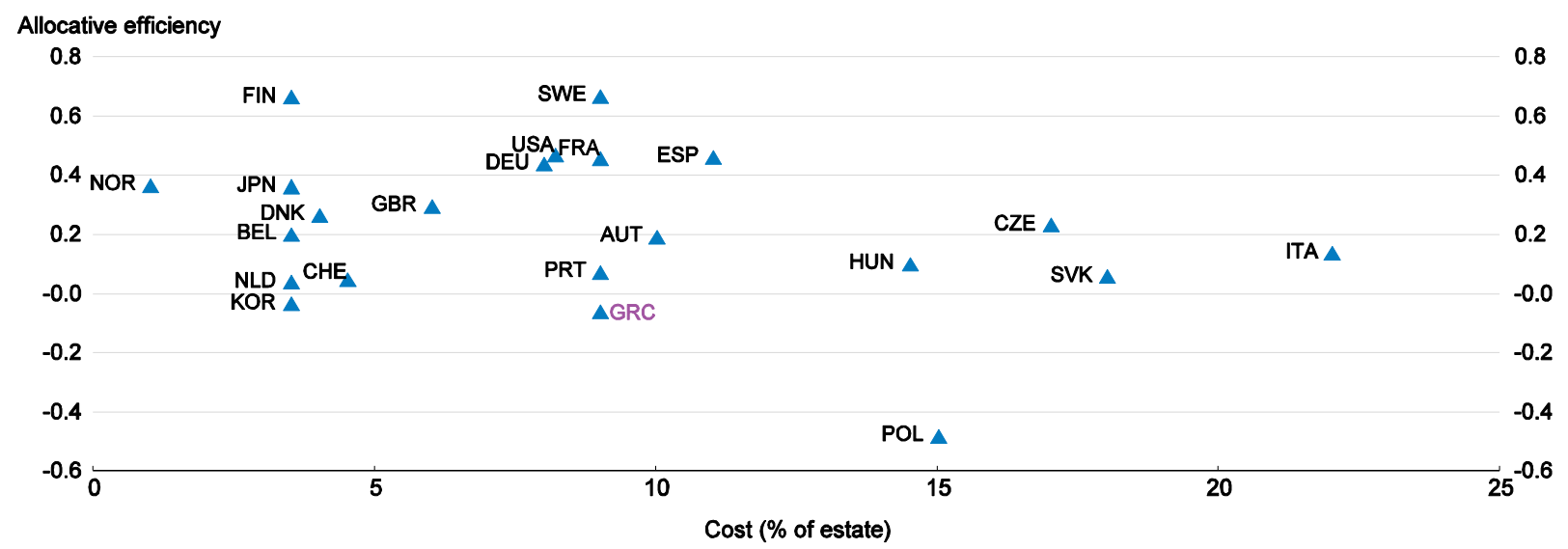

Note: As in Bartelsman et al., (2008), the index of allocative efficiency is a measure of the correspondence between firm size and labour productivity, which is computed for a large number of countries and industries. For more info see Andrews and Cingano (2014).

Source: World Bank Doing Business database; Andrews, D. and Cingano, F., (2014) Public Policy and Resource Allocation: Evidence from Firms in OECD Countries (April 2014). Economic Policy, Vol. 29, Issue 78, pp. 253-296, 2014. 
Figure 11. Bankruptcy procedures in Greece are time consuming and recovery rates are low

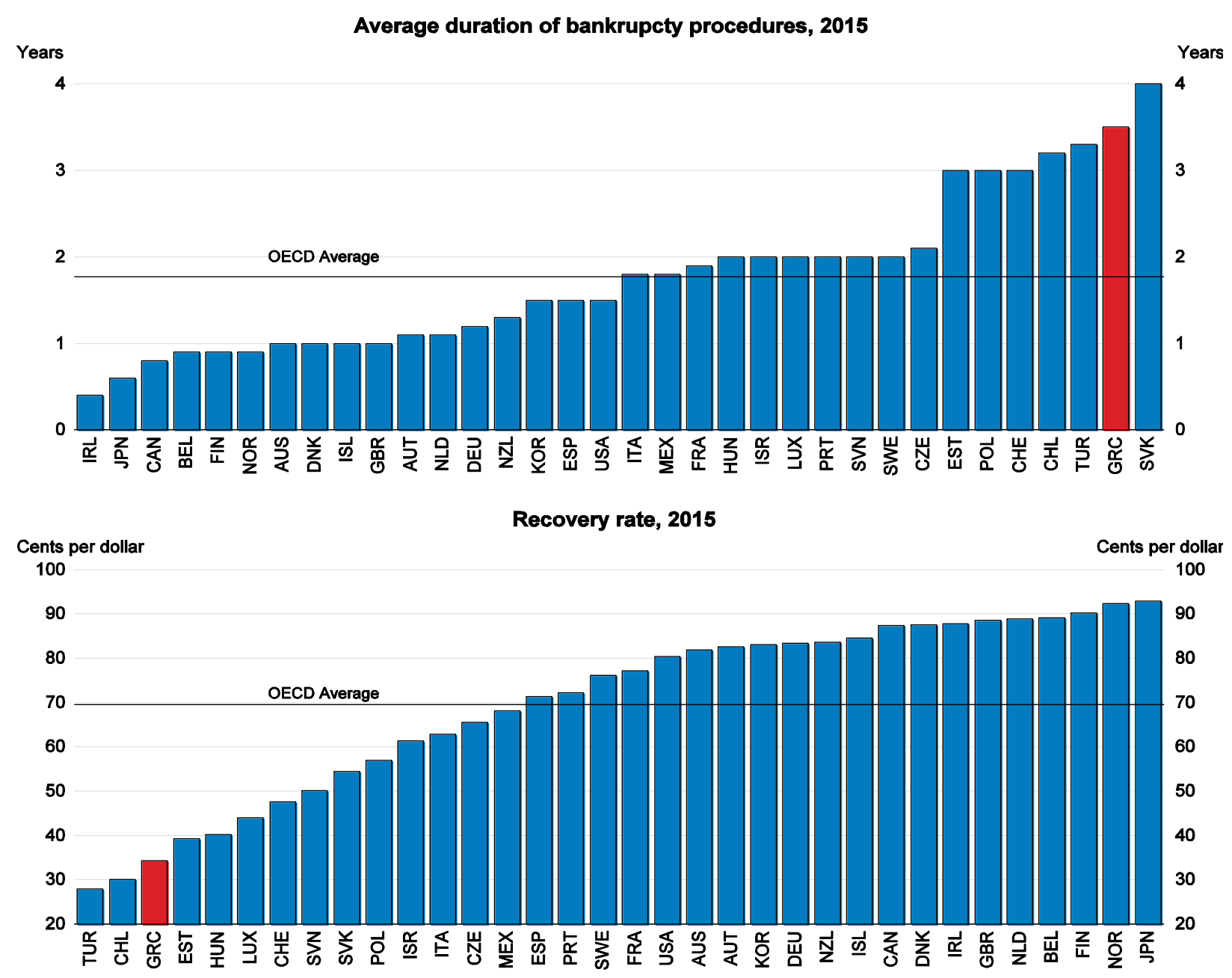

Source: World Bank (2015), Doing business database.

The estimated impact of the reform on GDP is around 0.2 percentage points in the next decade from catching up to the technological frontier and spill-over effects. However, this estimate does not fully take into account the effects on the efficiency in the allocation of resources, which could be sizeable. For example, a 'back of the envelope' calculation based on the correlation between allocative efficiency and the cost of bankruptcy (based on Figure 4) yields an increase by 4 percentage points in aggregate productivity (and output) for a given distribution of firms of these changes.

\section{Implementing the new Code of Civil Procedures is important for overall reform effectiveness}

An effective justice system is critical for the functioning of a market economy and fairness. A well-functioning legal system is accessible to all, and not just to the privileged. Furthermore, an effective judiciary is critical for the overall effectiveness of reforms in product markets, given that agents might only change their behaviour significantly if changes in regulations carry a reasonable probability of being enforced. A malfunctioning judiciary hinders economic and social development through different channels. Low effective investor protection, and slow judicial practices reduce the attractiveness to domestic and foreign investors. It can also lead to less favourable financing conditions, as weak creditor rights ends up pushing up interest rates and reducing debt maturity. 
The slowness of the Greek justice system reduces the credibility of the rule of law and contract enforcement. A clear sign of these inefficiencies is in the World Bank's Doing Business Indicators Greece ranks 132 out of 189 countries still in 2015 in terms of contract enforcement, the lowest among OECD countries (Figure 12).

Figure 12. Contract enforcement remains costly

Days to enforce a contract, 2015

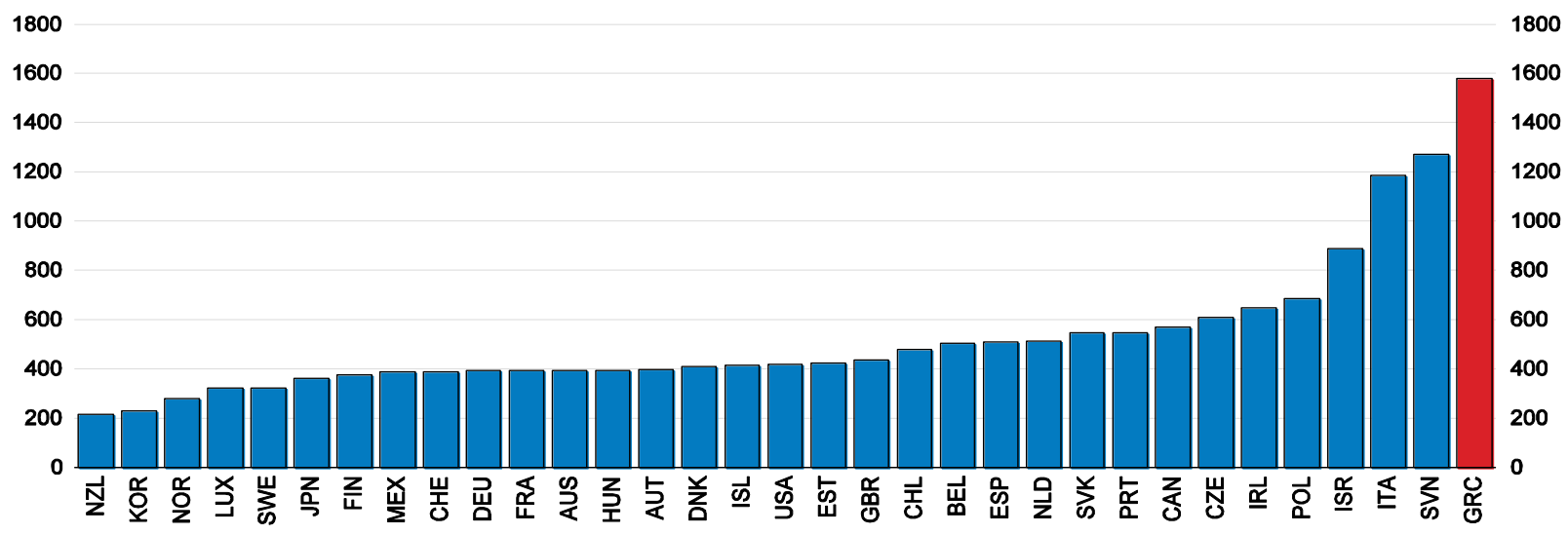

Source: World Bank Doing Business Database.

A New Civil Procedure Code was passed in July 2015 to address some major issues in the judiciary. Its main objectives are to speed up of trial completions - with a target of a case assessment of 160 days from the date the request is submitted - and strengthen the First Instance Courts. These courts are to undertake more responsibilities and process a larger number of cases. However, efficiency would be strengthened by a degree of specialisation of judges, as for example is the case in the recent judiciary reform of Italy (OECD, 2015b). Of course, so far these reforms only reflect primary legislation, and it will be important to implement them as soon as possible.

Additional measures are needed to improve the efficiency of the judiciary. For example, the digitalisation of the judiciary tools generally raises the productivity of judges and reduces trial length (Palumbo et al, 2013). The new Civil Procedure Code includes some measures that go in this direction, for example by introducing electronic updates, the option of e-signatures and optional electronic submission of trial documentation. However, making e-filing compulsory would speed up processes.

The caseload is increasing at an unsustainable pace, given current human and financial resources of the judicial system (Mitsopoulos and Pelagidis, 2011), suggesting a need for more judges and other judicial staff. Empirical evidence for Greece shows that increases in financial resources have not led to an improvement in the time needed to deal with cases (Mitsopoulos and Pelagidis, 2007). This means that more emphasis should be put on reducing judges' workload through alternative dispute resolution mechanisms, such as out-of-court settlements, which were recently introduced in Portugal. Model trials - the extension of a particular trial to other cases with identical characteristics - could also reduce the caseload, costs and uncertainty about rulings as well as create a greater incentive for out-of-court settlements by reducing the uncertainty of the outcome in case of litigation and therefore favouring a negotiation among the parties (Papaioannou, 2011). Another area for reform is the liberalisation of lawyers' fees, as the international evidence shows that this leads on average towards a reduction in litigation (Palumbo et al, 2013). 


\section{The pension reform is crucial to lift employment growth in the medium run}

Recent pension reforms focused on improving the system's long-term sustainability. Reforms to the pension system in 2010 strengthened the long-term viability of the system by aligning benefits more with contributions, including by increasing and equalising retirement ages, and enhanced equity (OECD, 2013). A means-tested basic pension for the uninsured or those with insufficient years of contributions was also introduced. However, inequalities remain as some professional groups, such as liberal professions, kept their independent and more generous schemes. Furthermore, although the structure of the system was simplified, leaving six pension funds (in the past there were more than 100), several different sectoral systems, with different social security contributions and benefits, still operate within these funds. The reform also included a clause that curbs pension expenditure increases until 2060 to a maximum of $2.5 \%$ of GDP, triggering otherwise the need for parametric adjustments. In 2012, further adjustments were introduced including lower pensions, curbs in the number of hazardous occupations, an increase in the retirement age to 67 by 2021 and linking it to increases in life expectancy thereafter, as well as merging supplementary pension funds into one single fund.

These reforms reduced projected long-term pension expenditures from $16.2 \%$ in 2013 to $14.3 \%$ of GDP by 2060 (EC, 2015b). The reforms resulted in a 30\% decline in gross replacement rates, which had been unsustainably high prior to the crisis. However, gross replacement rates still are above the OECD average (Figure 13).

However, there have been significant delays in implementing the reforms approved in 2010 and 2012. For example, in the cases of issuing regulations to incorporate supplementary pensions under a unified fund (ETEA), adopting ministerial decisions to implement provisions such as penalties for early retirement or issuing secondary legislation for early retirement in the public sector. OECD estimates show that full implementation of the above reforms and those contained in the $2015 \mathrm{MoU}$ with the creditor institutions could increase GDP by more than $2 \%$ in the next decade via employment growth.

Implementation was speeded up in the second half of 2015, but challenges remain. For example, the government has adopted secondary legislation and ministerial decisions to curb early retirement by increasing penalties and implementing restrictions to early retirement in the public sector (EC, 2015c). However, the decision by the Council of State in June 2015, which declared pension cuts undertaken in 2012 as unconstitutional, requires alternative legislation to neutralise its fiscal implications. Furthermore, a number of special regimes linked both to benefits and contributions still persist. For example, self-employed workers are allocated in 14 income levels regarding the income base on which the contributions are calculated, but they have the discretion of moving up to three income levels below the automatically assigned level. For some professions, such as self-employed engineers and lawyers, reduced contributions by $50 \%$ during the first five years of employment apply. Similarly, doctors and pharmacists enjoy reduced contributions by $40 \%$ for the first five years. Another preferential regime related to benefits of workers in agriculture is the provision of a basic pension (EUR 360 or less) without necessarily contributing to the system. Moreover, employees of certain banks who entered employment before 1993 can also retire particularly early: women at the age of 45 and with 20 years of contributions, and men at the age of 55 with 25 years of contributions. The existence of these different regimes points to a need for a rationalisation of exceptions to target those in need while, at the same time, safeguarding the viability of the social security system. 
Figure 13. Pension reforms have improved the system's long-term sustainability

Gross replacement rate, single person ${ }^{1,2}$

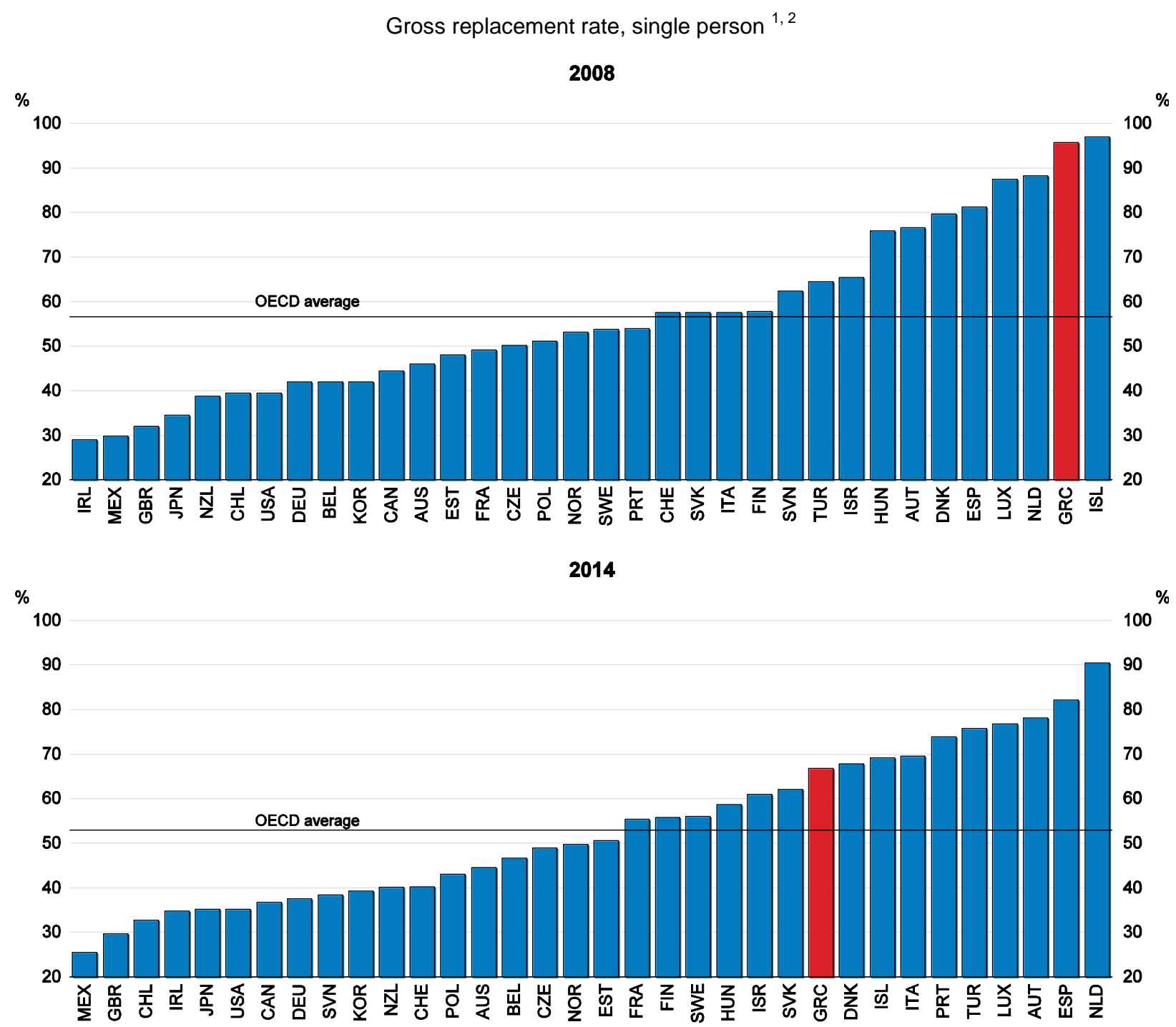

1. The gross replacement rate is defined as gross pension entitlement divided by gross pre-retirement earnings. It is a measure of how effectively a pension system provides income during retirement to replace earnings, the main source of income prior to retirement.

2. The replacement rate for Greece does not take into account supplementary pensions.

Source: OECD (2015) Pensions at a Glance.

While the changes in the pension system if fully implemented will gradually reduce spending pressures over the next decades, today's expenditure on pensions remains high compared to other OECD countries. While old-age expenditure represented more than half of total social expenditure in Greece in 2012, the EU average amounted to less than $40 \%$. The deep economic crisis has also contributed to push up public pension expenditures as percentage of GDP. Therefore, despite the reforms discussed above, public expenditure on pensions increased from 12.3\% of GDP in 2008 to $17.7 \%$ of GDP in 2014 (Figure 14). These figures do not change significantly if private pension schemes, which are important in several OECD economies (e.g. Denmark, Netherlands, United Kingdom and United States) but marginal in Greece, are included in the analysis. The government presented a pension reform programme in 
January 2016. It would abolish all special pension regimes, restructure the supplementary pension and create a general common defined-benefit pillar, and a basic pension financed with general tax revenues. Although several of the details are still under negotiation with social partners and the creditor institutions, the targeted savings would be an additional $1 \%$ of GDP. Such a reform would also reduce the remaining horizontal and vertical inequalities in the pension system due to special regimes and potentially free some fiscal resources for other social expenditures, for example the minimum income guarantee, school meals or housing assistance.

\section{Figure 14. Public expenditure on pensions remains very high}

\section{Gross public expenditure as percentage of GDP}

\section{8}

$\%$

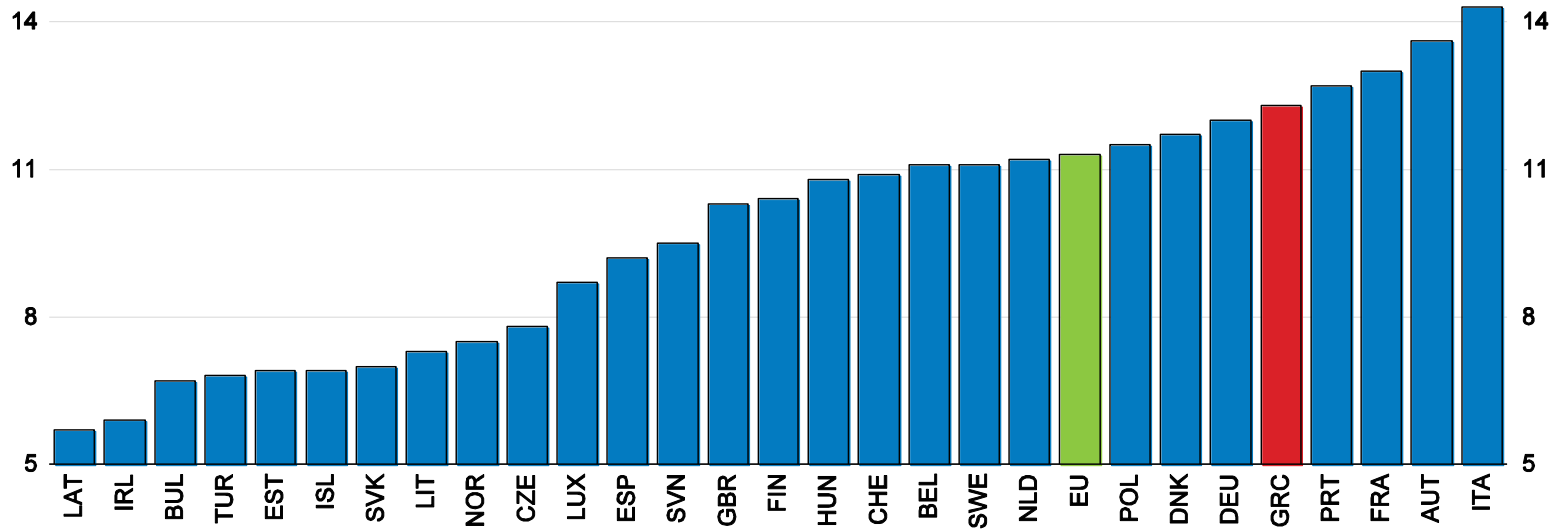

2013 or latest available data

$\%$

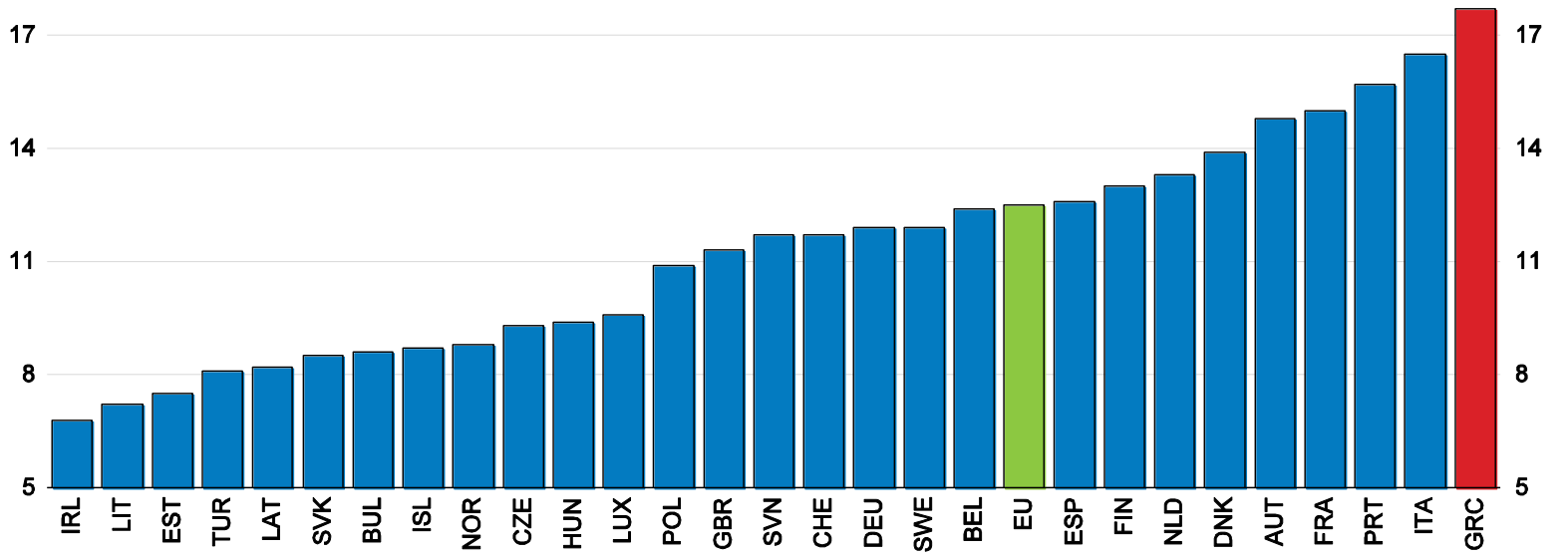

Source: Eurostat. 


\section{Labour market reforms are bearing some fruits already}

\section{Labour market rigidities and work disincentives were high before the crisis}

Labour market outcomes before the crisis reflect a combination of restrictive labour market regulations and disincentives to work. Greece had very low job reallocation and creation rates, even during the economic expansion that took place after joining the Euro area in the early 2000s (OECD, 2010b). Other indicators are also consistent with significant distortions in the labour market. For example, labour force participation rates (especially for women) were significantly below the OECD average. In addition, the structural unemployment rate was on average at $11 \%$ during the 2000-08 economic expansion, compared to an OECD average of $6.5 \%$ and a Euro area average of a little less than $9 \%$. Finally the very high share of self-employment, above 35\% of total employment, compared to around 5\% around the OECD or the Euro area, reflect the predominance of SMEs in the Greek economy and high levels of informality in the Greek labour market (Figure 15).

\section{Figure 15. Labour market performance was weak before the crisis}

(Averages for 2000-08)
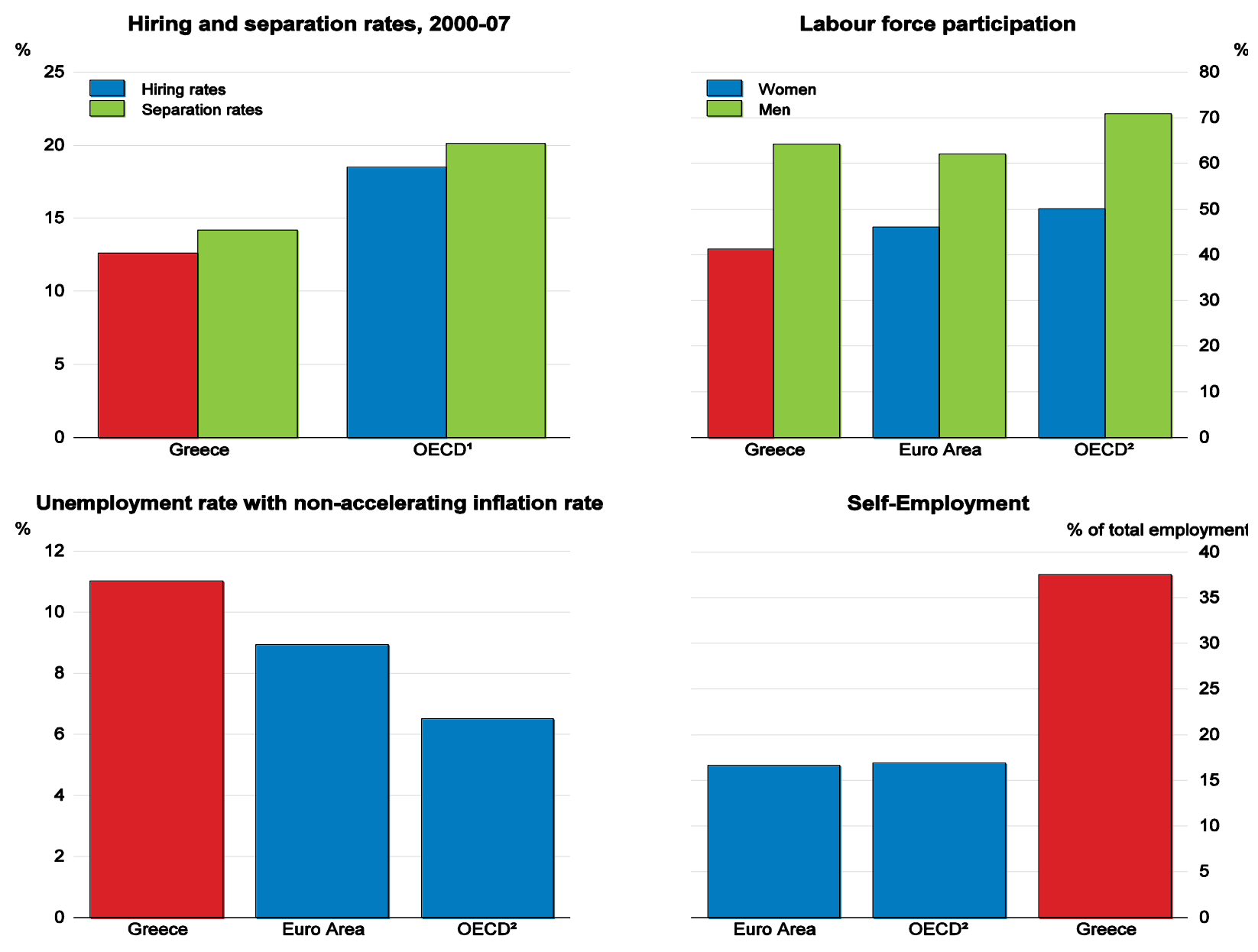

1. In this graph, OECD is a simple average OECD selected countries (ITA, SVK, HUN, SVN, CZE, PRT, BEL, AUT, NLD, DEU, SWE, NOR, FRA, POL, ESP, FIN, DNK, TUR and ISR).

2. OECD is a weighted average of the 34 OECD countries.

Source: OECD (2010b) Employment Outlook; OECD Economic Outlook 98 database; OECD Labour department database. 
Before the crisis, Greece had one of the most restrictive employment protection legislation among OECD countries (Figure 16). In particular, long notice periods, large severance payments, and restrictions to collective dismissals reduced hiring and firing rates and therefore the job reallocation and job creation processes. Moreover, the wage bargaining framework, in particular the automatic extension of collective agreements, made wages more rigid to adjust to firm-specific needs and less aligned with productivity developments. Furthermore, generous pay and job stability in public enterprises and the public administration required the private sector to follow similar practices if it wanted to attract workers (Lyberaki et al., 2015). On the other hand, compared to other OECD countries the effect on minimum wages in Greece on earnings inequality and employment does not appear to have been particularly large (Koske et al., 2012).

\section{Figure 16. Employment protection legislation was restrictive before recent reforms}

(Index between $0-6$ from least to most restrictive)

2008

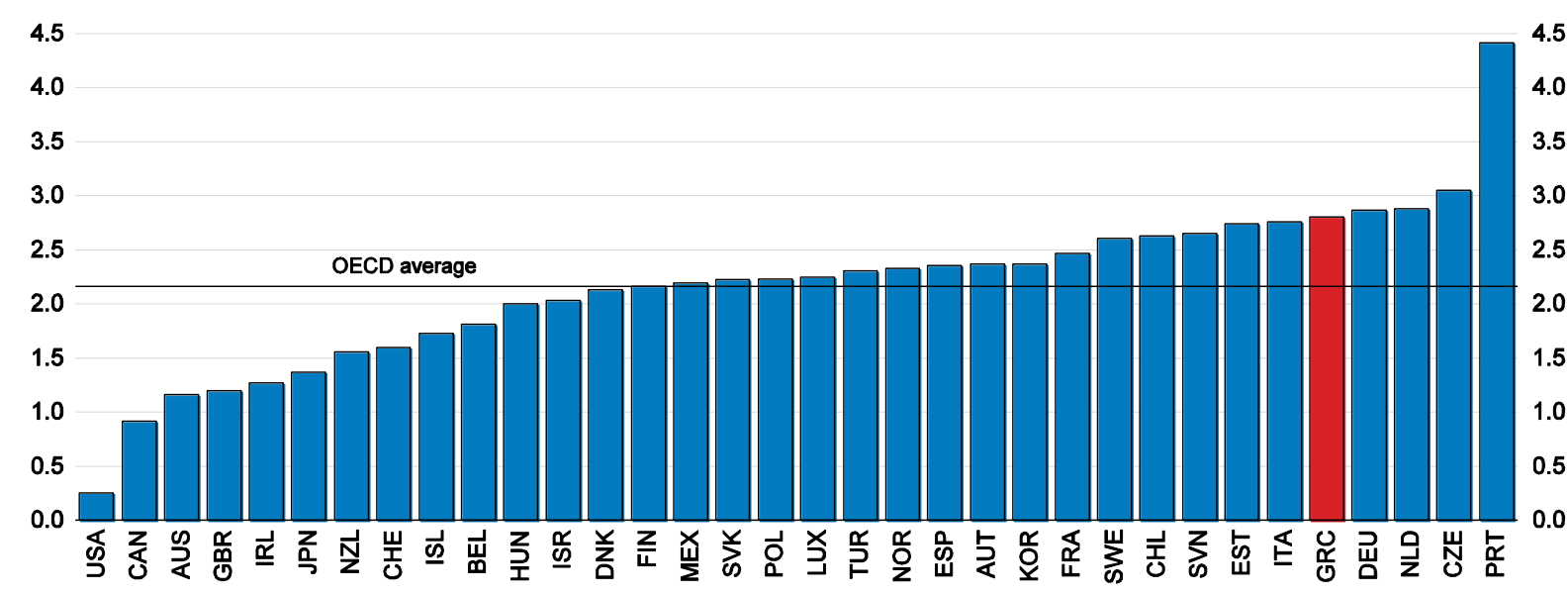

2013

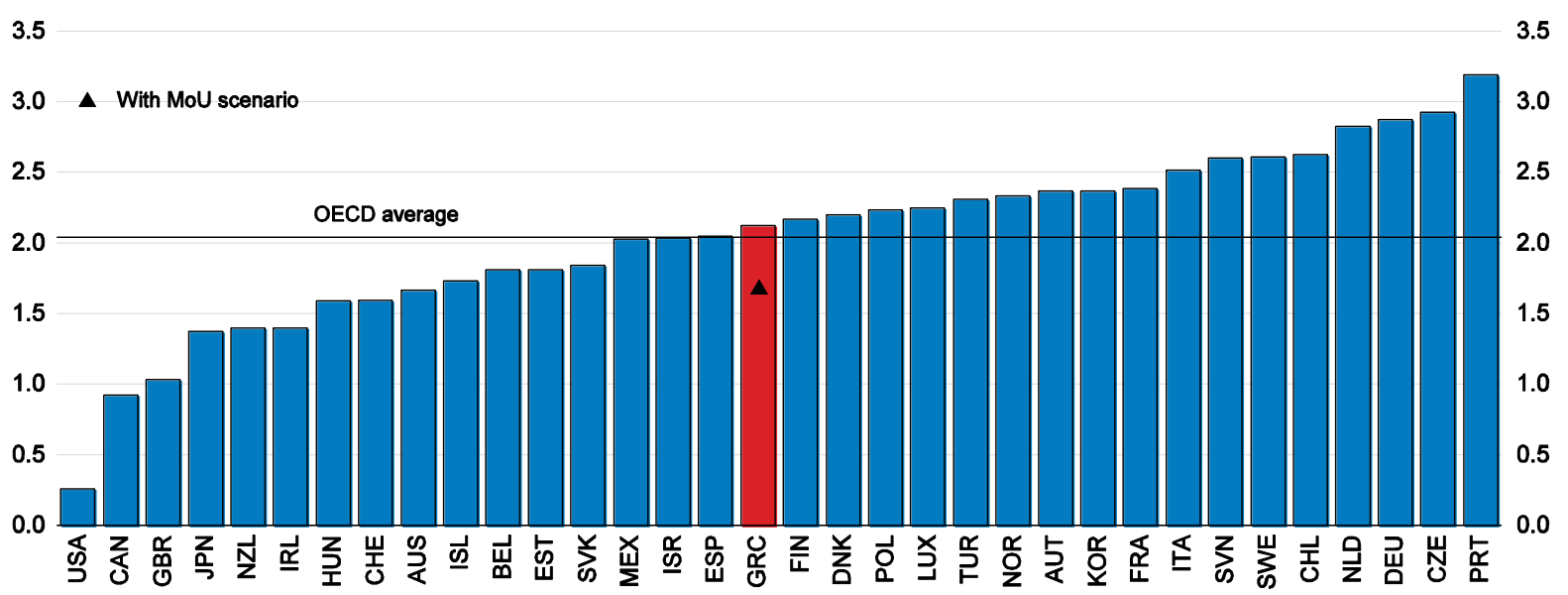

Source: OECD (2015) Labour and social protection directorate database. 
Overall, these labour market rigidities also explain the adjustment dynamics in the Greek labour market in the aftermath of the crisis, characterised by a significant increase in unemployment and a rather gradual adjustment in private sector wages. For example, while the unemployment rate soared from $7.7 \%$ to $17.9 \%$ between 2008 and 2011, private sector wages only declined by $4 \%$ in nominal terms during the same period.

The tax and benefits system also blunted incentives for work. The average tax wedge in Greece increased steadily between 2000 and 2007 from $39 \%$ to above $42 \%$, compared to a slight decline in the OECD average from $36.8 \%$ to $36.2 \%$, and it remains above the OECD average (Figure 17). Furthermore, after the crisis, tax hikes to achieve fiscal consolidation, such as increases in employers' and employees' social security contributions and increases in the personal income tax (such as the solidarity contribution), have kept taxation on labour above the OECD average. However, while for workers at the lower end of the tax wedge remained relatively stable and close to the OECD average, for higher wage earners the increase was steep, expanding from $45 \%$ in 2000 to above $49 \%$ in 2006, more than 8 percentage points above the OECD average. While these changes make the tax system more progressive, they might also reduce incentives for entrepreneurship and spur under-reporting of income by self-employed higher-income individuals. High replacement rates for pensions and generous regulations regarding early retirement also discouraged the participation of elderly workers (see above).

Figure 17. Taxation on labour is still relatively high in Greece

Average tax wedge, single person at $100 \%$ of average earnings, no child

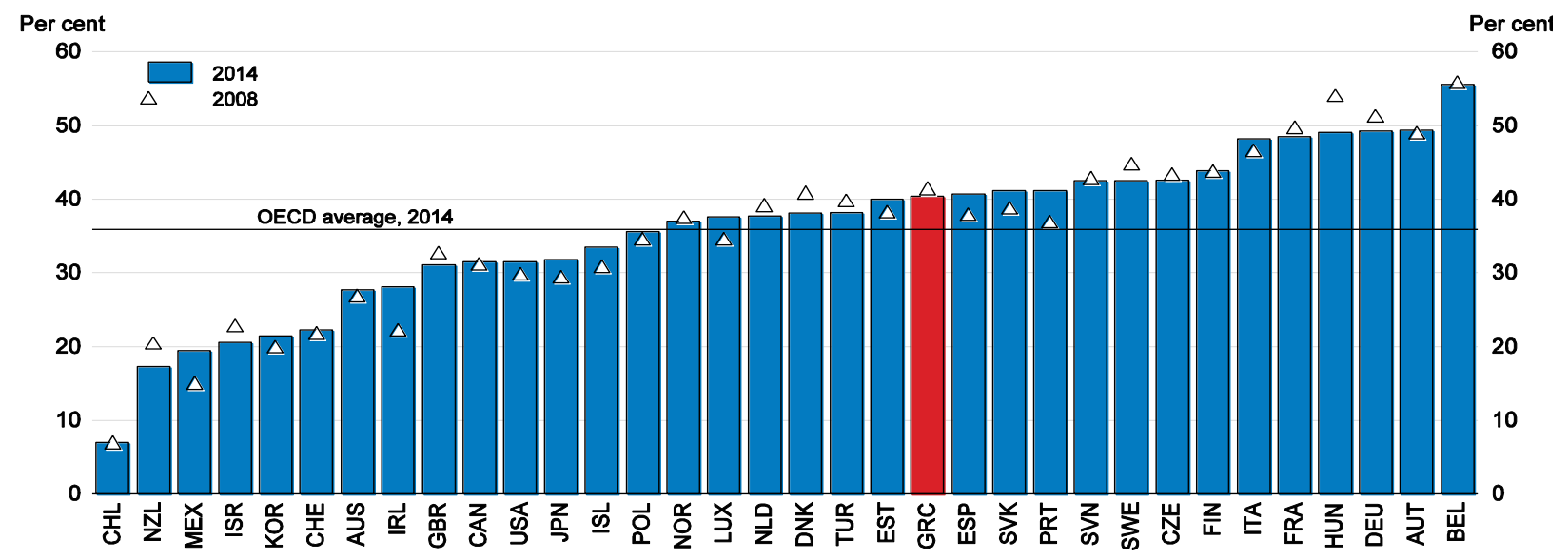

Source: OECD (2015) Taxing wages database.

Despite increases in female labour participation during the crisis, it is still low compared to OECD countries. Low female labour force participation in Greece is explained by a series of public policies regarding childcare and social norms. The Greek tax system has preferential treatment for two-income households and there is little evidence of childcare affordability problems (Figure 18). However, low public expenditure on childcare restrains the supply of childcare services (OECD, 2013b; EC, 2009).

In the past, restrictions on part-time work reduced the opportunities for women to participate in the labour market (Lyberaki et al., 2015). Although these restrictions have been lifted, several remain, especially in the public sector which should act as a leader with respect to the private sector. Although the share of part-time working women who would prefer working full time increased from $42 \%$ in 2009 to $65 \%$ in 2014 , their overall share in the labour force (3.6\% in 2014) is still low compared to the OECD average of $5.5 \%$. This means that there seems to be room for increasing voluntary part-time work among women. Encouraging firms to move towards more flexible work arrangements -in particular for white collar workers- such as for example using teleworking more extensively would also favour female participation in the labour market. 
Figure 18. The tax treatment of double-income households is favourable and childcare is affordable, but low expenditure on childcare reduces its availability

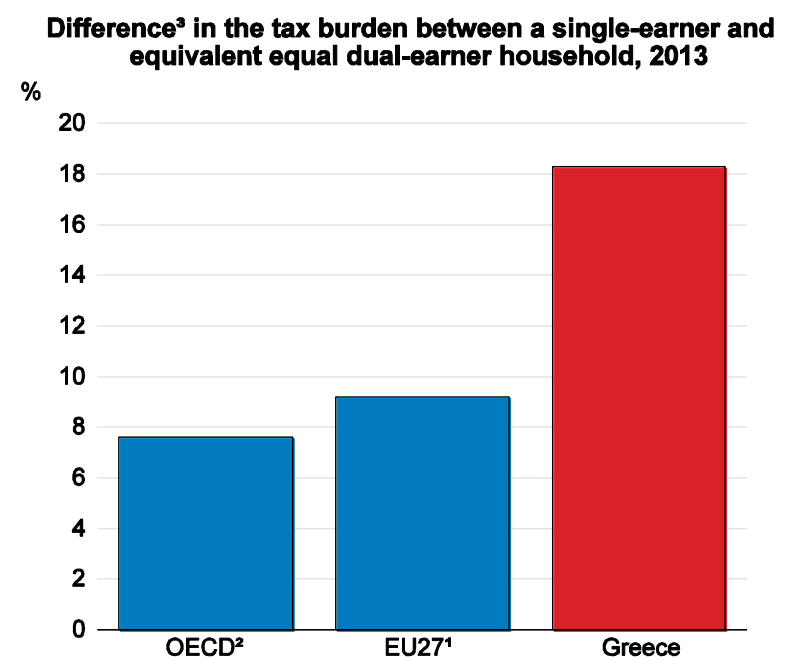

Childcare fees per two-year old attending accredited early-years care and education services, 2012

$\%$ of average wage

30

25

20

15

10

\section{5}

$$
0
$$

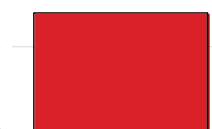

Greece

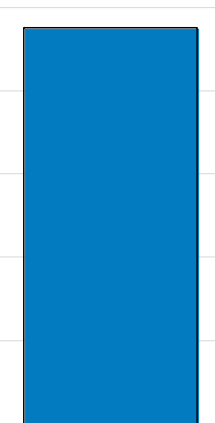

EU27

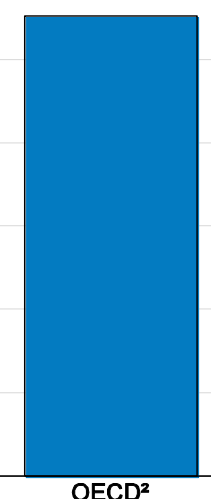

$\mathrm{OECD}^{2}$
Average enrolment rate of children aged three to five years of age in pre-school educational programmes

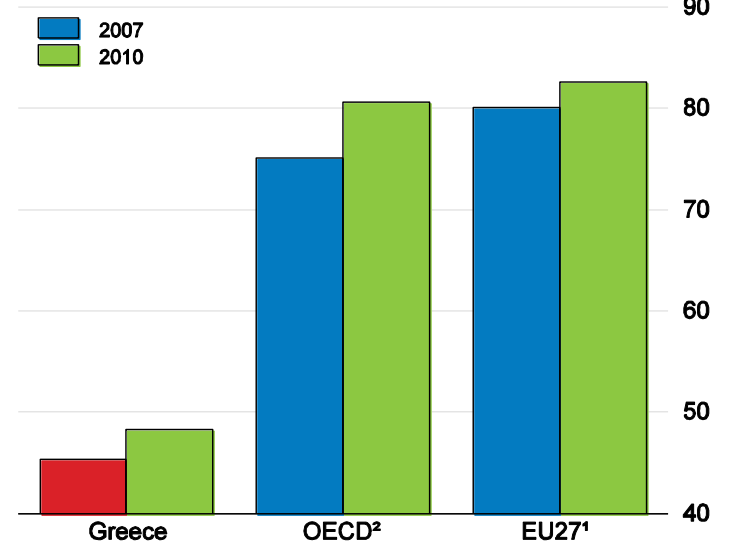

Public expenditure on childcare and pre-school

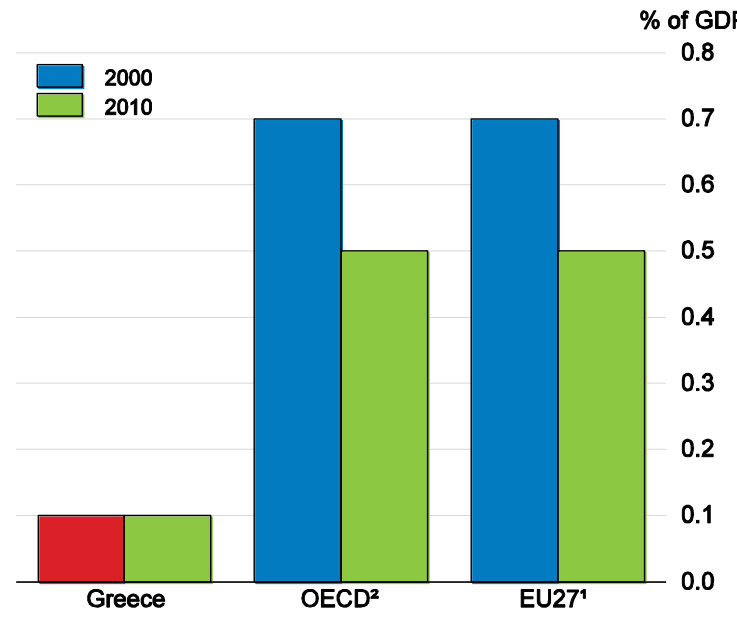

1. Simple average of the $27 \mathrm{EU}$ countries members of the OECD.

2. Simple average of the 34 OECD countries.

3. Difference in average taxes and contributions paid as percentage of gross household earnings, between a couple with two children age 6 and 11 with a single earner earning 200\% of average worker earnings and a couple with two earners earning $100 \%$ of average worker earnings.

Source: OECD Education database; Canada, National Longitudinal Survey of Children and Youth (2010); Korea, Ministry of Health and Welfare (2010), and EU-SILC 2010 for other European countries. OECD Tax-Benefit model 2014. OECD 2012 Tax-Benefit model. Social Expenditure database 2014; OECD Education database.

\section{The short-term costs of increased labour market flexibility have been distributed unevenly}

Since 2010, a series of labour market reforms have been implemented that were intended to introduce more flexibility. In terms of collective bargaining, firms are no longer required to follow sector-wide salary agreements, even if the firm-level agreements are less generous. Furthermore, size restrictions regarding the minimum number of employees to have a firm-level agreement were eliminated. 
Employment protection legislation and the minimum wage were also reformed. The prior notice period of dismissal has been reduced from 24 months for white-collar workers to a maximum of four months. Severance payments have been reduced and are now subject to a ceiling of 12 months' salary. The probation period for new hires (not temporary) has been increased from 2 to 12 months. These reforms have brought Greece close to the average OECD performance in terms of employment protection legislation. Although there are still relatively stringent restrictions on collective dismissals and the use of fixed-term contracts, the large rise in unemployment during the recession suggests that labour market today is sufficiently flexible to ensure a job-rich recovery if demand conditions improve and complementary product market reforms are implemented. At the end of 2011, the minimum wage was reduced by one third in nominal terms and a lower minimum wage for vulnerable groups was introduced. Furthermore, the minimum wage setting process was changed from being bargained between employers and workers associations to being set directly by the government, allowing for the level of unemployment to be taken into account.

The Greek minimum - median wage ratio for single workers with no experience wage currently stands well below the OECD average (Figure 19). However, the minimum wage increases with seniority, a unique case among OECD countries, which makes the effective minimum wage higher. The minimum wage for workers under-25 years old without experience is EUR 511 per month, while the minimum wage for workers over 25 years old without experience amounts to EUR 586 per month. However, for each three years of experience it increases by EUR 58 up to nine years and for some married workers, there is an additional premium of EUR 58, such that it can go up to EUR 818. The revision of the minimum wage is due in 2016. It should be looked at in light of productivity and fairness considerations, including a revision of the seniority premium.

Figure 19. The minimum wage in Greece is relatively low ${ }^{1}$

Minimum wage as percentage of median wage, 2014

$\%$

70
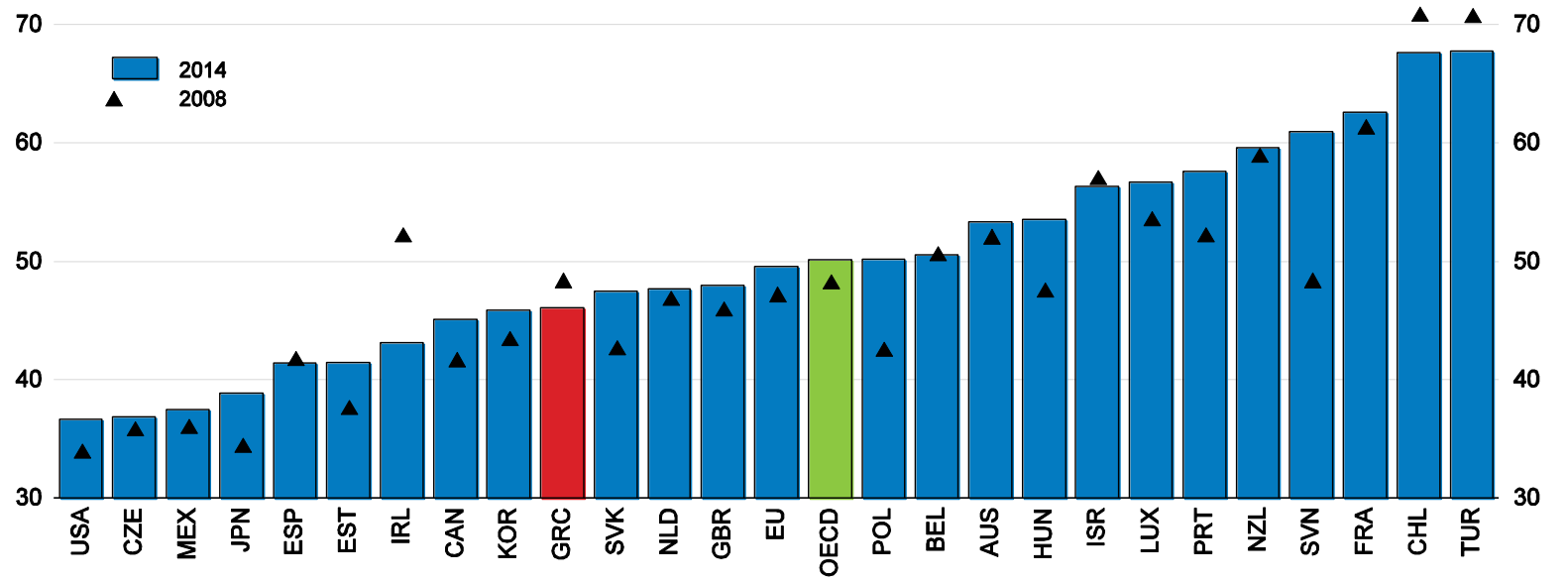

1. For Greece single, worker with no work experience.

Source: OECD (2016) Employment Outlook Database. 
Labour market reforms are already changing labour market dynamics in Greece. While wages in the past did not react to changes in local labour market conditions (Daouli et al., 2013a), there is evidence that they have become more responsive to changes in local unemployment rates after the reforms (Cholezas and Kanellopoulos, 2015).

However, the effect of labour market reforms on job creation has been dampened by weak domestic and external demand. Despite the significant decline in labour costs, the internal devaluation has led to little overall growth and job creation in the Greek economy, although some rebalancing towards export activities seems to be underway. An additional factor might have been a suboptimal sequencing of product and labour market reforms. In particular, in situations like Greece before the crisis - where labour and product market regulations were highly restrictive - reducing product market restrictions before addressing employment protection legislation leads to better effects on employment on average than proceeding the other way around (Fiori et al., 2012).

In the short-term, reforms that eased employment protection legislation led to higher unemployment but should now be contributing to employment growth as the economy recovers. Labour market reforms tend to generate greater labour market turnover, which plays an important role in the reallocation process of workers and therefore for productivity growth. Based on OECD-wide estimates, the effect of employment protection legislation reforms on the annual probability of becoming unemployed in Greece increased on average by 1.4 percentage points. This is an economically significant effect compared to the approximate $10 \%$ average probability of becoming unemployed for the 2005-11 period (Garda and Cournede, 2016). In contrast, while the effects on job loss tend to be felt very quickly, the benefits in terms of increasing the probability of becoming employed in general take between two to three years to materialise (Bouis et al., 2012). In the medium run, the average probability of becoming employed would increase by 1.6 percentage points, which is sizeable compared to an average probability of around $18 \%$ for 2005-11.

A more decentralised wage bargaining framework has led to more firm-level agreements. This should have positive effects for efficiency, as firm-specific circumstances can be taken into account, granting more overall flexibility. However, it can also lead to more labour income inequality if the firm-level bargaining power of workers is low. Evidence shows that recent firm-level negotiations were more favourable to workers in firms where a trade union existed before the wage bargaining reform, controlling for other firm or sector characteristics (Daouli et al., 2013b).

Employment protection legislation reforms have been especially costly in terms of job opportunities for low-income individuals. While the probability of becoming unemployed increased by 2.4 percentage points for individuals in the first income quartile, it did so only by 1 percentage point for the upper quartile. Likewise, there is no significant increase in the probability of becoming employed for workers within the three lowest quartiles of the income distribution, while this probability increased by almost 3 percentage points for individuals in the highest income quartile. Additional policies to mitigate these differences are therefore needed to avoid them translating into higher inequality via differences in employment opportunities (see below). Differences in employment rates were already an important factor in driving inequality in labour earnings before the crisis (Hoeller et al., 2012).

\section{Better public employment services and vocational education and training}

As the economy expands again, a key challenge will be to the get the unemployed -many of whom will have been unemployed for a long period- back to work. Employment creation has been surprisingly resilient during 2015, despite high economic uncertainty in the first half of the year and the recessionary impact of the subsequent bank holiday and capital controls. The resolution of uncertainties regarding the agreement with the institutions and the clear political mandate of the new government to implement this 
agreement are key factors that will provide stability for job creation to continue in 2016. With the economic recovery gaining traction, it will be important to make job recovery intensive and tackle long-term unemployment.

Maximising the use of EU funding through the European Social Fund and the Youth Employment Initiative will help create more training opportunities in the short term. In the past, Greece has faced delays in executing the allocated funds, due to capacity constraints and more recently financial constraints to provide the national co-financing part. The latter constraint has been relaxed by reducing the co-financing requirements. However, to make fast and efficient use of the available funding, it is important to speed up the preparation and selection process of projects; improve budget planning and have more coordination of all EU funding at the central government level. This would allow for more unemployed people to be reached by the planned guaranteed employment support scheme, which includes active labour market measures; vocational education, and training programmes; more traineeships and apprenticeships and a voucher programme to help create jobs for young workers. More recently, several of these schemes have already been launched.

The fastest possible implementation of the public employment service (OAED) modernisation plan would help raise the quality of active labour market policies (OECD, 2013a). Together with the implementation of VET and apprenticeship plans, this could prove crucial to reintegrating the unemployed into the job market. To increase the relevance of VET offers and anticipate future needs, plans should be evaluated systematically; employers should be more involved and a system to detect current and future needs in terms of skills-needs should be created. Such measures would smooth the transition from the education system to the labour market, which was already difficult before the crisis (OECD, 2010b).

\section{Future changes in labour market institutions should balance efficiency and equity}

The $2015 \mathrm{MoU}$ foresees potential changes to collective dismissals, collective bargaining and wage setting, as well as strikes and industrial action. An expert commission with the support of international organisations will produce a review on these issues, which will be discussed between social partners, the government and the institutions. According to OECD estimates, bringing collective dismissal legislation towards the least restrictive standards, similar to Finland today, would boost GDP by 0.2 percentage points in the next ten years (see Table 2). This rather modest estimate suggests that solutions that ensure sufficient flexibility to support job creation and growth and a proper balance between collective dismissal procedures and individual dismissal protection for workers are important. These estimates do not take into account the potential dynamic effects on productivity growth due to a more efficient reallocation of labour in the economy, which are often found to be more significant.

The previous collective bargaining system contributed to a growing misalignment between labour costs and productivity, which required a painful adjustment process during the crisis to correct. Therefore, reverting to the previous system should be avoided. The OECD experience shows that sector-level bargaining often pushes wages upwards in times of boom and delays the required wage-adjustments in times of crisis, particularly in the presence of heterogeneous firm performances (OECD, 2013b). In the past, several OECD countries moved towards more centralised negotiations or more coordinated bargaining which enables all sides to internalise the effects on unemployment and inflation.

However, in most OECD countries, firm-level negotiations have increased their importance in the last two decades. This has happened mainly through having sectoral agreements that basically set out the framework for firm-level agreements within each sector rather than establishing the wage increases and the inclusion of derogation clauses that allow firms to deviate from the sectoral agreement under certain preestablished conditions (OECD, 2013b). In principle, a sector-based bargaining system that allows for derogation clauses can be as flexible as a more decentralised system (Jimeno and Thomas, 2013). 


\section{Tax and benefit reforms should aim at supporting more inclusive growth}

\section{The changes in the tax mix will boost growth}

Since 2010, important changes in taxation have taken place. Overall, fiscal consolidation was based on increasing the share of indirect taxes as well as taxes on immovable property, which should boost growth by improving incentives to work and invest. The latest VAT reform will broaden the tax base. Overall, these reforms have a strong impact on output, raising it by an estimated 2.1 percentage points over the next decade.

In the medium run, if tax evasion is reduced, it could therefore lead to some fiscal space for lowering the corporate income tax and the labour tax wedges and making property taxation more progressive. This would lead to a more growth-friendly and fairer tax system, including for the export sector. For example, the property tax could be improved by a combination of tax administration and policy changes. Improving the fiscal cadastre to include all relevant aspects of properties would increase equity. While businesses are not subject to the supplementary tax on property, reducing the property tax burden of businesses would make the property tax more progressive and encouraging for firms. At the same time, the corporate income tax -at a rate of $29 \%$ - is indeed significantly above the average of the OECD countries (25\% statutory rate in 2015), which might make Greece less attractive to foreign direct investment (FDI).

\section{Fiscal adjustment was overall progressive, but contributed to increased poverty}

Early fiscal consolidation policies per se appear to have had a small impact on inequality and relative poverty, partly mitigating the effects of the recession (Figure 20). As consolidation intensified in 2012, the measures appeared to have contributed to rising poverty. From 2013 onwards, fiscal consolidation measures have had a more equalising effect, especially at the bottom of the distribution and in terms of its distance from the top. At the same time, the proportion of the population whose income fell below a real-terms poverty line anchored in 2005 increased with each round of consolidation: it was given a further boost by the rise in unemployment until 2014 when it finally partially reverted (OECD, 2013b; Leventi and Matsaganis, 2016).

The results from micro-simulations suggest that measures which either placed a greater burden on high incomes, or mostly affected households at the top of the income distribution (such as cuts in public sector pay and pensioners' solidarity contributions), cushioned the impact on inequality (Table 3). On the contrary, policies adversely affecting low-income households (such as the 2012 cut in unemployment benefits), or easing the burden on higher incomes (such as the 2013 income tax changes) had an opposite, inequality-increasing effect. More specifically, micro-simulation estimates for the period 2010 to 2014 indicate that changes in child benefits, pensioners' solidarity contribution (in effect, a rather steep levy on higher pensions), and cuts in public sector pay were progressive (Table 3). Furthermore, changes in personal income taxes (in 2010-2011 and 2014), cuts in pension benefits (in 2010), and reductions in property taxation (in 2013) also seemed to have a progressive -though weaker- effect.

A strong progressive impact can be seen -for example- in the case of direct tax changes in 2010, with the greatest losses incurred by the top decile, while public pension cuts affected mostly the middle of the distribution. On the other hand, some policies - such as the introduction of emergency property tax in 2011; the cut in unemployment benefits in 2012; the changes in personal income tax in 2013 and the changes in property taxation in 2014 - had a large negative impact on the lowest deciles (Leventi and Matsaganis, 2016). 
ECO/WKP(2016)22

Figure 20. The effects of tax-benefit reforms and the recession on inequality and poverty
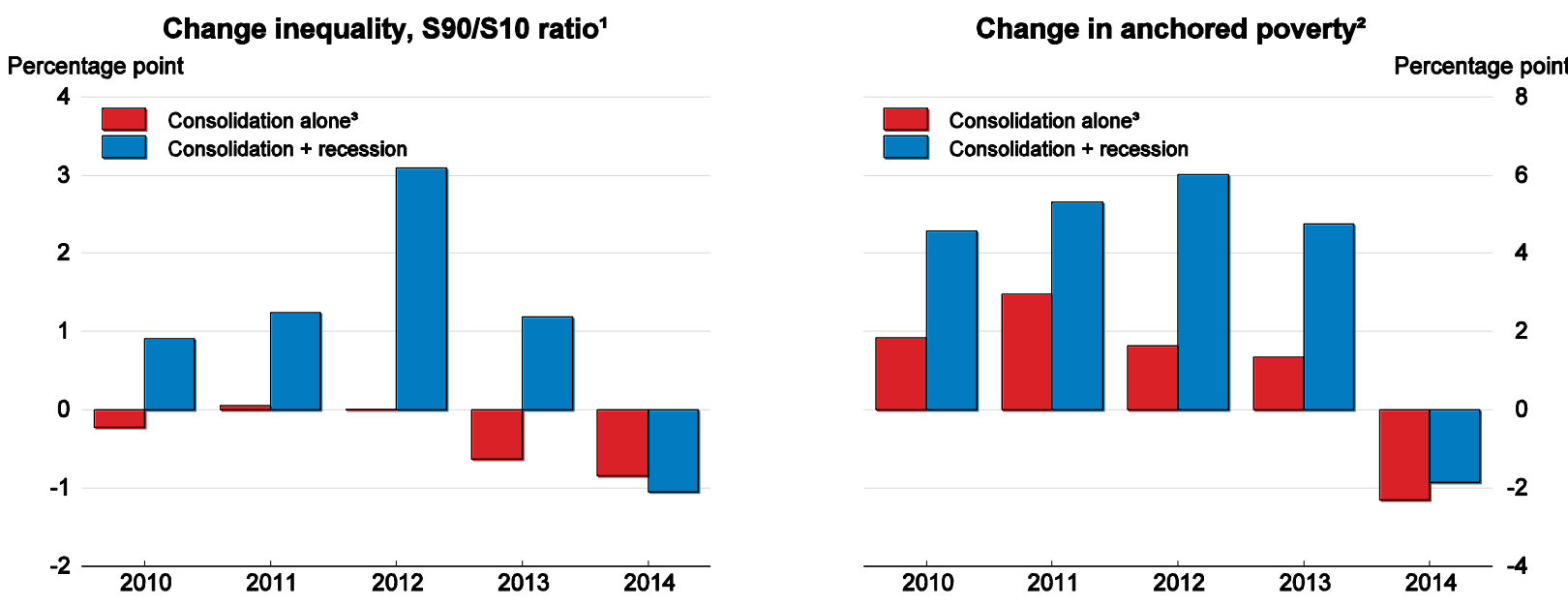

1. The S90/S10 ratio is calculated as the ratio of the mean income received by the $10 \%$ of the population with the highest income to that received by the $10 \%$ of the population with the lowest income.

2. The poverty line is fixed at $50 \%$ of median equivalised household disposable income in 2005

3. The impact of consolidation policies in year $\mathrm{t}$ is assessed relative to the state of the economy in $\mathrm{t}-1$, which is equivalent to assuming that government policies altered public sector pay, public pensions, taxes and benefits, but left nominal pre-tax market incomes and employment levels as in the year before.

Source: Leventi and Matsaganis (2016) based on micro-simulation analysis (EUROMOD).

Table 3. The effect of individual fiscal consolidation policies on inequality

\begin{tabular}{|c|c|c|c|c|c|}
\hline & \multicolumn{5}{|c|}{ Changes in the Gini index (in percentage points) $^{1}$} \\
\hline & 2010 & 2011 & 2012 & 2013 & 2014 \\
\hline income taxes & 0.00551 & 0.00388 & no change & -0.00520 & 0.00019 \\
\hline public sector pay & 0.00165 & 0.00016 & 0.00079 & 0.00122 & no change \\
\hline pension benefits & 0.00075 & no change & no change & -0.00193 & no change \\
\hline pensioners' solidarity contributions ${ }^{2}$ & 0.00041 & 0.00048 & 0.00180 & 0.00073 & no change \\
\hline social insurance contributions & no change & 0.00008 & -0.00005 & -0.00010 & -0.00004 \\
\hline self-employed \& liberal prof. contribution & -0.00030 & -0.00012 & -0.00030 & no change & no change \\
\hline property taxes ${ }^{3}$ & no change & -0.00252 & no change & 0.00045 & -0.00074 \\
\hline child benefits $^{4}$ & no change & no change & no change & 0.00661 & no change \\
\hline EKAS $^{5}$ & no change & no change & no change & no change & -0.00080 \\
\hline unemployment insurance benefit & no change & no change & -0.00107 & no change & no change \\
\hline
\end{tabular}

1. The table shows the percentage point difference between the counterfactual value of the Gini coefficient in the absence of all consolidation measures presented in the table for a specific year (i.e. on the basis of previous year's policies) relative to its value after the implementation of the austerity measure in question. Positive (negative) values indicate progressive (regressive) impact. For a detailed description of policies see Leventi and Matsaganis (2016).

2. Solidarity contributions levied on main and supplementary pensions.

3. Emergency property tax in introduced in 2011 ; reduced by $15 \%$ in 2013 ; replaced by "single tax on immovable assets" in 2014, when additional tax on rental income is abolished.

4. $\quad 3^{\text {rd }}$ child benefit, birth grant and lifetime pension for mothers of many children abolished, large family benefit became meanstested, single child benefit introduced in 2013.

5. EKAS: Income-tested supplement aimed at recipients of old age and survivor pension. Age threshold raised from 60 to 65 in 2014.

Source: Leventi and Matsaganis (2016) based on micro-simulation analysis (EUROMOD). 


\section{A better social safety net to support inclusive growth}

Overall social expenditure remains around the EU average as share of GDP. The latest available detailed figures on social expenditures are for 2012, which show that family-related social benefits were low in per capita terms, while old-age benefits were generous compared to the OECD and EU averages (Figure 21). However, social expenditures have been part of the consolidation effort and they have been restructured and made more targeted and less generous. This has contributed to a reduction in overall social expenditures by two percentage points of GDP between 2012 and 2014.

However, social expenditure remains highly concentrated on old-age, mainly via pensions, while the poverty profile has been shifting significantly. Child poverty is increasing, while old-age poverty continues to fall, at least when considering the relative poverty line of $50 \%$ of median income. Some of the recent changes in benefits have reduced but not reversed child poverty and old-age poverty (e.g. the single child benefit and the numerous-family benefit and the social dividend, respectively).

\section{Figure 21. The composition of social expenditures does not match the changing social challenges}

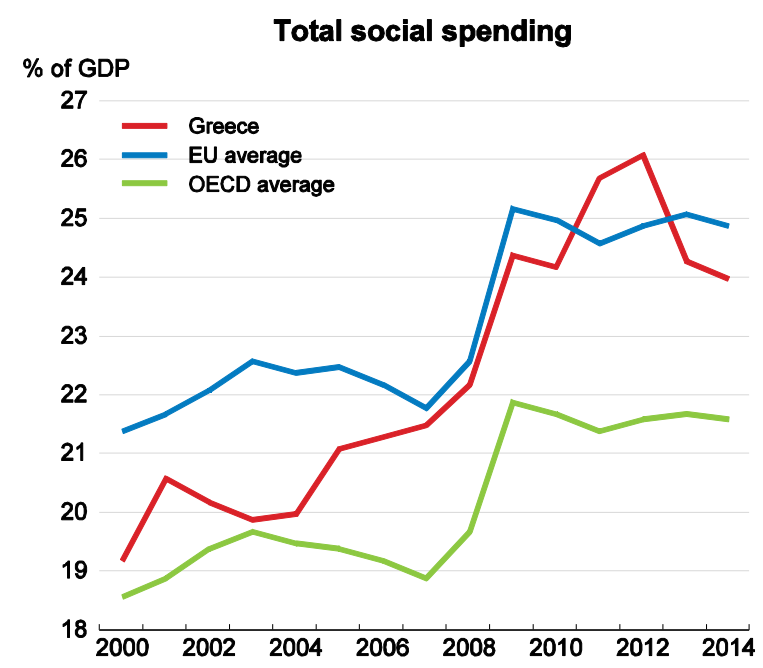

Old-age and family expenditures, latest data USD (thousands), constant prices, per head

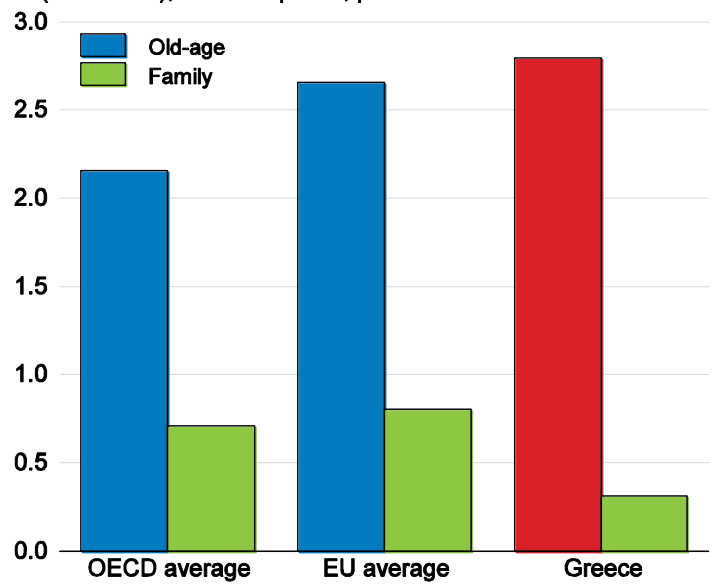

Poverty rate ( $50 \%$ of median income) after taxes and transfers $\%$ of respective population

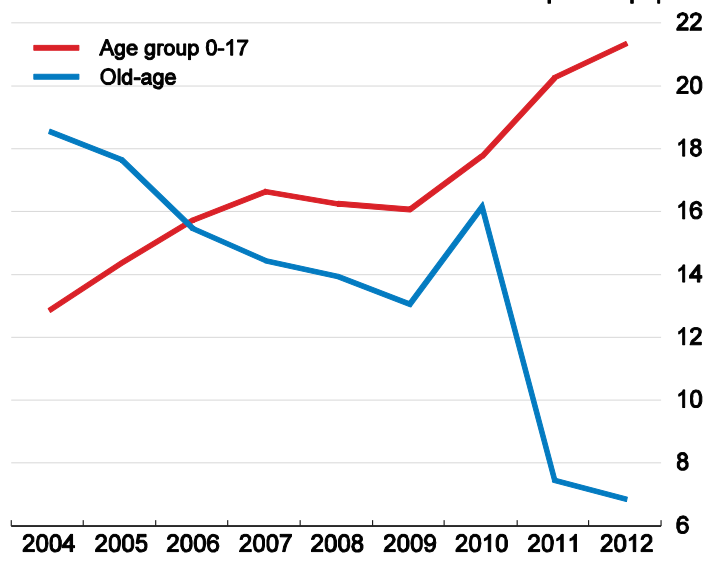

Family expenditures, latest data $\%$ of GDP 3.0

Cash benefits Benefits in kind

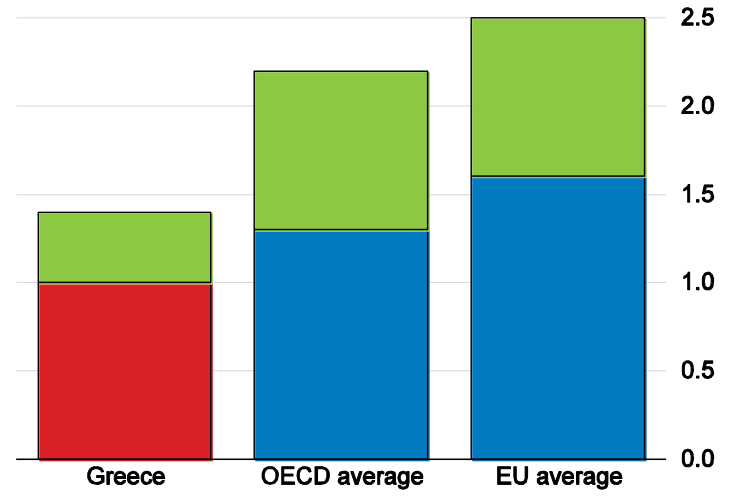

Source: OECD Social policy database and Eurostat. 
Implementing the means-tested guaranteed minimum income (GMI) scheme -under which households with low income and little assets would be eligible for income support- would help to ease some of the social consequences of the crisis. It will replace some of the emergency ad-hoc programmes (most importantly food stamps and subsidies in energy and rent), but will require more resources. A pilot scheme conducted in 13 municipalities was launched in November 2014. Households were eligible for the scheme if the taxable value of their main residence was below EUR 90000 and their disposable income was below EUR 2400 per year (increased by EUR 1200 per year for each additional adult in the household and EUR 600 per year for each child). The benefit level was set equal to the difference between the income ceiling and the household's income. A recent World Bank study estimates that rolling out this scheme at a national scale would cost around $0.5 \%$ of GDP per year and could raise the income of the poorest and reduce extreme poverty (World Bank, 2015a). The GMI will be phased in during the second half of 2016 and rolled out fully in 2017.

More actions are needed now to address child poverty. As recommended in the 2013 Economic Survey, a means-tested subsidised school meals programme would reduce food insecurity among children from poor households. Examples of such programmes can be seen in France, the United States and the United Kingdom. A preliminary estimate puts the cost of such a programme at around $0.4 \%$ of GDP per year. However, the inexistence of school meal programmes in state-schools and potential under-reporting of income make means testing less effective. A more suitable alternative for the short-run would be to introduce school meal programmes in schools located in low-income regions.

Furthermore, the most vulnerable households face significant and mounting pressure of housing-related expenditures compared to other EU countries (Figure 22). Moreover, homelessness has increased significantly since 2009 (OECD, 2013b). The previous main housing subsidy (OEK) was abolished in 2012 and there is no social housing programme. While a social housing programme would be the best solution in the medium run, introducing a well-targeted housing assistance programme is a priority for dealing with this problem in the short run. Assuming that such a programme would be similar in size as the previous OEK subsidy, this would amount to around $0.5 \%$ of GDP per year.

Figure 22. Housing problems among the vulnerable population are widespread

Housing cost overburden rate ${ }^{1}$

Total population

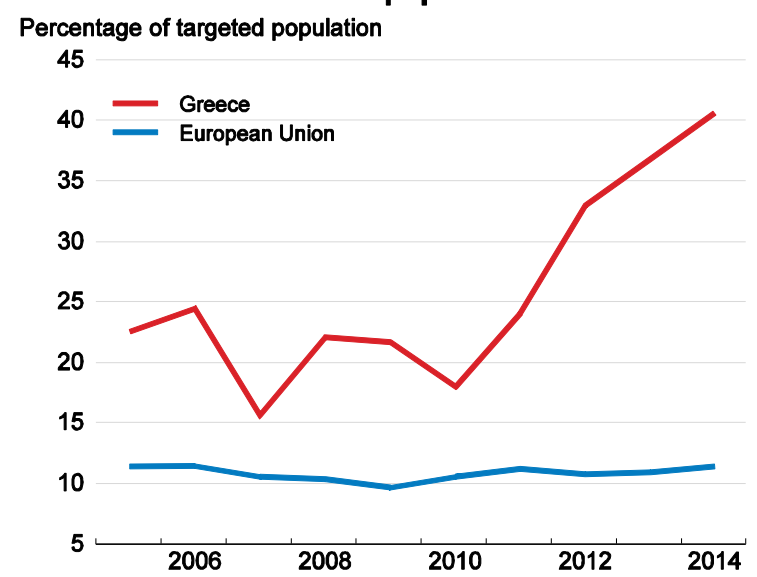

Population with income below $60 \%$ of median equivalised income Percentage of targeted population

100

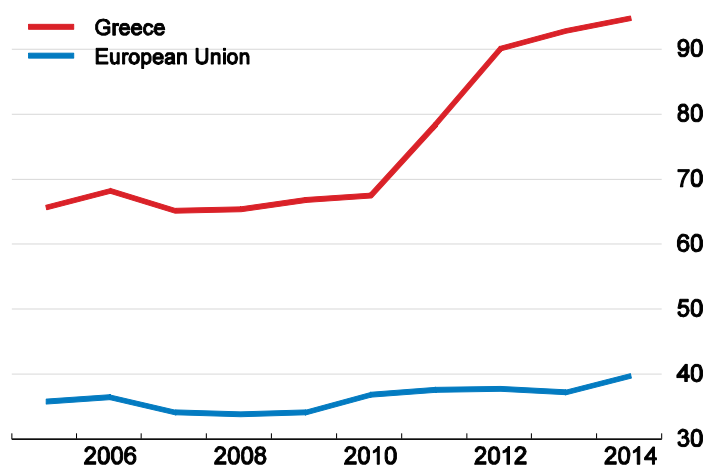

1. This indicator is defined as the percentage of the population living in a household where the total housing costs (net of housing allowances) represent more than $40 \%$ of the total disposable household income (net of housing allowances) presented by household type.

Source: Eurostat 


\section{ECO/WKP(2016)22}

In the current tight fiscal situation, financing these programmes -which would represent around $1.5 \%$ of GDP- presents a challenge. Given the urgency of addressing the social crisis, the government should aim at alternatives such as allocating part of the resources from savings generated elsewhere, e.g. pensions or defence, or improvement in tax collection to covering a gradual implementation of the scheme. The completion of the social welfare review, which is currently being undertaken together with the World Bank, and the expenditure review foreseen for 2016 will be important instruments for identifying sources for efficiency gains among social programmes and for resource reallocation within the public sector. At the same time, programmes will be more effective if they are implemented properly. For example, to make the GMI highly progressive, more efforts should be made to develop a means-testing tool that overcomes the potentially severe underreporting of income. Results from the pilot programme also show that local governments need more technical support from the national level to better target the guarantee (Jessoula et al, 2015).

\section{Recommendations on structural reforms for inclusive growth}

\section{Key recommendations}

- Ease regulations in network industries and strengthen the capacity and independence of regulatory agencies.

- Implement the 2012 Better Regulation Law.

- Reduce delays and backload of cases in the judiciary by using more e-justice tools, training judges, implementing out-of-court settlements, model cases, and specialised competition courts.

- Undertake an expenditure review to create fiscal space for strengthening the social safety net and expanding active labour market policies.

- Conclude the reform of the pension system including a review of special regimes and introducing a basic pension in a fiscally sustainable way.

- Speed up the modernisation of the public employment service (OAED).

- Implement the minimum income guarantee, a targeted school meal programme for poor children and a well-targeted housing assistance programme.

- Reform labour market institutions and review the minimum wage taking into account equity and efficiency considerations.

\section{Further recommendations}

- Increase reform ownership by quantifying and communicating the benefits of reforms.

- Build capacity to assess the impact of reforms and reinforce coordination across line ministries.

- Strengthen the Hellenic Competition Commission's advocacy work by allocating more resources to its work outside the area of law enforcement.

- In the event of a major exogenous adverse shock, avoid as much as possible large tightening of discretionary fiscal policy, taking into account fiscal targets.

- Facilitate licensing by implementing a one-stop shop for operating a business and reduce regulatory burden by using regulatory impact assessments and policies such as "one-in two-out" more systematically.

- Reduce restrictions to competition in sectors such as manufacturing, construction and wholesale.

- Increase the supply of childcare services and encourage flexible work arrangements. 


\section{BIBLIOGRAPHY}

Andrews,D. and F. Cingano (2012), "Public Policy and Resource Allocation: Evidence from Firms in OECD Countries", OECD Economics Department Working Papers, No. 996, OECD Publishing. DOI: http://dx.doi.org/10.1787/5k9158wpf727-en

Blanchard, O. and D. Leigh (2013), "Growth Forecast Errors and Fiscal Multipliers" International Monetary Fund Working Papers, 13/1, Washington, DC.

Bouis, R., O. Causa, L. Demmou, R. Duval, A. Zdzienicka (2012), "The Short-Term Effects of Structural Reforms: An Empirical Analysis", OECD Economics Department Working Papers, No. 949, OECD Publishing, Paris. DOI: http://dx.doi.org/10.1787/5k9csvk4d56d-en

Cholezas, I. and N.C. Kanellopoulos (2015), "Labour market reforms in Greece and the wage curve," Economics Letters, 136: pp. 19-21.

Daouli, J., M. Demoussis, N. Giannakopoulos, and I. Laliotis (2013a), The wage curve during the great depression in Greece 8th IZA/World Bank Conference on Employment and Development.

Daouli, J., M. Demoussis, N. Giannakopoulos, and I. S. Laliotis (2013b). "The Impact of the 2011 Collective Bargaining Reform on Wage Adjustments in Greece." Department of Economics, University of Patras, Draft Paper.

European Commission (2009), The provision of childcare services - A comparative review of 30 European countries, Luxembourg: Office for Official Publications of the European Communities. doi: $10.2767 / 10651$

European Commission (2015), The 2015 Ageing Report: Economic and budgetary projections for the 28 EU Member States (2013-2060).

http://ec.europa.eu/economy_finance/publications/european_economy/2015/ee3_en.htm

Fiori, G., G. Nicoletti, S. Scarpetta, and F. Schiantarelli (2012), "Employment effects of product and labour market reforms: Are there synergies?” Economic Journal 122 (February), pp. 79-104.

Garda, P. and B. Cournède (2016), Who gains and loses from structural reforms? Preliminary results on labour-market consequences for individuals across OECD countries OECD Economics Department Working Paper, forthcoming.

Hoeller, P., I. Joumard, M. Pisu and D. Bloch (2012), Less Income Inequality and More Growth - Are They Compatible? Part 1. Mapping Income Inequality Across the OECD, OECD Economics Department Working Papers, No. 924, OECD Publishing. http://dx.doi.org/10.1787/5k9h297wxbnr-en

IMF (2014), IMF Country Report on Greece No. 14/151, Washington, DC. 
Jessoula, M., M.Matsaganis and M. Natili. 2015. "Strengthening minimum protection in southern and eastern Europe? Pressures from within and from beyond". 22nd International Conference of Europeanists, Paris, 8 July

Jimeno, J.F. \& C. Thomas (2013), "Collective bargaining, firm heterogeneity and unemployment," European Economic Review, vol. 59(C), pages 63-79, Elsevier.

Katsoulacos, Y., C. Genakos and G. Houpis (2015), Product Market Regulation and Competitiveness: Towards a National Competition and Competitiveness Policy for Greece, Athens University of Economics, Athens.

Koske,I., J. Fournier and I. Wanner (2012), "Less Income Inequality and More Growth - Are They Compatible? Part 2. The Distribution of Labour Income", OECD Economics Department Working Papers, No. 925, OECD Publishing, Paris. DOI: http://dx.doi.org/10.1787/5k9h2975rhhf-en

Leventi, C. and M. Matsaganis (2016), "Estimating the distributional impact of the Greek crisis (20082014)," OECD Economics Department Working Papers, forthcoming.

Lewis, C. and N. Pain (2014), "Lessons from OECD forecasts during and after the financial crisis", $O E C D$ Journal: Economic Studies, Vol. 2014/1. http://dx.doi.org/10.1787/eco_studies-2014-5jxrcm2glc7j

Lyberaki, A., C. Meghir and D. Nicolitsas (2015), "Labour Market Regulation and Reform in Greece," in C. Pissaridis, C. Meghir, D. Vayanos and N. Vettas (eds.), Crisis in the Eurozone Periphery: Policy Options for Greece, MIT Press, Cambridge MA.

Mitsopoulos, M., and T. Pelagidis (2007). "Does staffing affect the time to dispose cases in Greek courts?" International Review of Law and Economics 27(2): 219-244.

Mitsopoulos, M., and T. Pelagidis (2011). Understanding the Crisis in Greece: From Boom to Bust. Basingstoke, Hampshire: Palgrave Macmillan.

OECD (2010a), Making Reform Happen: Lessons from OECD Countries, OECD Publishing, Paris. DOI: http://dx.doi.org/10.1787/9789264086296-en

OECD (2010b), OECD Employment Outlook 2010: Moving beyond the Jobs Crisis, OECD Publishing, Paris.

DOI: http://dx.doi.org/10.1787/empl_outlook-2010-en

OECD (2013a), The 2012 Labour Market Reform in Spain: A Preliminary Assessment, OECD Publishing, Paris.

DOI: http://dx.doi.org/10.1787/9789264213586-en

OECD (2013b), OECD Economic Surveys: Greece 2013, OECD Publishing, Paris.

DOI: http://dx.doi.org/10.1787/eco_surveys-grc-2013-en

OECD (2014a), OECD Competition Assessment Reviews: Greece, OECD Publishing. http://dx.doi.org/10.1787/9789264206090-en 
OECD (2014b), Measurement and Reduction of Administrative Burdens in Greece: An Overview of 13Sectors, OECD Publishing, Paris.

http://dx.doi.org/10.1787/9789264213524-en

OECD (2015a), Economic Policy Reforms 2015: Going for Growth, OECD Publishing, Paris.

DOI: http://dx.doi.org/10.1787/growth-2015-en

OECD (2015b), OECD Economic Surveys: Italy 2015, OECD Publishing, Paris.

DOI: http://dx.doi.org/10.1787/eco_surveys-ita-2015-en

OECD. (2016), OECD Economic Surveys: Greece 2016, OECD Publishing, Paris.

DOI: http://dx.doi.org/10.1787/eco_surveys-grc-2016-en

Palumbo, G., G. Giupponi, L. Nunziata, J.S. Mora Sanguinetti (2013), "The Economics of Civil Justice: New Cross-country Data and Empirics", OECD Economics Department Working Papers, No. 1060, OECD Publishing. http://dx.doi.org/10.1787/5k41w04ds6kf-en

Papaioannou, E. (2011). "The Injustice of the Justice System," mimeo, (http://greekeconomistsforreform.com/wp-content/uploads/injustice_Papaioannou.pdf).

Saia, A., D. Andrews and S. Albrizio (2015), "Productivity Spillovers from the Global Frontier and Public Policy: Industry Level Evidence", OECD Economics Department Working Papers, No. 1238, OECD Publishing, Paris. http://dx.doi.org/10.1787/5js03hkvxhmr-en

Terzi, A. (2015), "Reform momentum and its impact on Greek growth," Bruegel Policy Contribution Issue $2015 / 2$.

World Bank (2016), Doing Business: Measuring Regulatory Quality and Efficiency, Economy Profile 2016 Greece, World Bank, Washington DC. 


\section{TECHNICAL ANNEX: SIMULATING THE LONG-RUN IMPACT OF STRUCTURAL REFORMS ON OUTPUT}

Quantification of structural reforms is based on the OECD's Going for Growth framework of policy indicators and empirical estimates of the relationship between policy and economic outcomes. This is founded an on extensive research programme over many years to understand these relationships.

Three types of structural reforms are considered: product market reforms, labour participation reforms and job-friendly labour market reforms.

For each type of reform, three OECD inputs are used:

1. A numerical indicator of the policy stance in each area (PMR, EPL, labour force participation).

2. A policy shock to the indicator reflecting reforms.

3. An estimate of the impact of changes in the indicator on structural productivity or labour force participation after 10-years.

\section{Effects of structural reforms on productivity}

Effects on multifactor productivity growth of product market reform (PMR) reforms

The framework used in based on Bourlès et al. (2010), column (4), Table 1:

Multifactor productivity (MFP) is assumed to follow an error correction model (ECM) of the form:

$$
\Delta \ln M F P_{i, j, t}=a_{0} \Delta \ln M F P_{F, j, t}+a_{1} g a p_{i, j, t-1}+a_{2} R E G_{i, j, t-1}+a_{3} R E G_{i, j, t-1} \times g a p_{i, j, t-1}+f_{i}+f_{j, t},
$$

where $M F P_{i, j, t}$ is the MFP level of a non-frontier country-sector pair $i, j$ in year $t, M F P_{F, j, t}$ is the MFP level at the technological frontier $F$ for sector $i$ in year $t, R E G_{i, j, t}$ is the OECD's regulatory impact indicator which measures regulatory burdens stemming from anti-competitive product market regulations in upstream sectors - in each country/sector/year triad, ${ }^{2}$ and $g_{a p} p_{i, j, t}$ is the country-sector distance from the sector frontier in year $t$, defined as:

$$
\operatorname{gap}_{i j, t}=\ln \left(\frac{M F P_{F j, t}}{M F P_{i j, t}}\right) .
$$

2. This indicator is calculated for each country by using total input-output coefficients as follows:

$$
R E G_{j, t}=\sum_{k} N M R_{k, t} \times w_{k, j},
$$

where $\mathrm{NMR}_{\mathrm{k}, \mathrm{t}}$ is the OECD indicator of anti-competitive regulation in non-manufacturing sector $k$ in year $t$ and the weight $\mathrm{w}_{\mathrm{k}, \mathrm{j}}$ (comprised between 0 and 1 ) is the total input requirement of sector $j$ for intermediate inputs from nonmanufacturing sector $k$. 
$f_{i}$ and $f_{j, t}$ denote respectively sector and country-year fixed effects. Estimates (over the 1995-2007 period for 24 OECD countries) indicate that the leader country's MFP growth in a particular sector has a positive impact on MFP growth in that same sector in less productive countries (technological pass-through effect), with $a_{0}=0.122$, while the gap variable also has a significant and positive effect on MFP growth (technology catch-up effect), with $a_{1}=0.032$. Importantly, the indicator of regulatory burden has a negative influence on MFP growth $\left(a_{2}=-0.124\right)$. This effect is found to be even more negative for country/sector/period triads close to the technological frontier, as suggested by the positive coefficient on the interaction term $\left(a_{3}=0.132\right)$.

\section{Effects on labour productivity growth of employment protection legislation (EPL) reforms}

The framework used in based on Bassanini et al. (2009), equation (2) in Table 6 (p. 383) and equation (5) p. 384:

The dynamics of labour productivity is given by the following equation (an error-correction framework in which the long-term gap between labour productivity in the country considered and the leading country depends on the stringency of EPL for regular workers and other constant unobserved factors, see Bassanini et al. 2009 for details):

$$
\log \Pi_{t}=(1-\phi) \log \Pi_{t-1}+\beta \lambda E P L R_{t-1}+\phi \log \Pi^{*}+c,
$$

where $\Pi$ is the aggregate labour productivity level in the country considered, EPLR is the OECD EPL index for regular employment, $\Pi^{*}$ is the aggregate labour productivity level in the productivity leader, $\phi=$ 0.02 and $\beta=-0.174$ as estimated by Bassanini et al. (2009), and

$$
\lambda=\sum_{j} \theta_{b j} \times\left(\text { Layoff }_{j}^{U S}-4\right)
$$

is a measure of the extent to which EPL puts effective constraints on labour turnover across the economy, with $\theta_{b j}$ the value added share of the "EPL-binding" industry $j$ and Layoff $f_{j}^{U S}$ the average layoff rate of industry $j$ in the United States over 2001-03. An industry is said to be "EPL-binding" if its layoff rate (defined as the ratio between annual recorded layoffs in a particular year and wage and salary employment of that year) was greater than $4 \%$ in the United States over $2001-03 .{ }^{3,4}$ Data on value added at the industry level comes from the OECD STAN database (Structural Analysis Database) for OECD countries (except for Mexico and Turkey) and from UNIDO for other G20 countries. ${ }^{5}$

3. Such a criterion is needed because the analysis carried out in Bassanini et al. (2009) is a differences-in-differences approach that only identifies the impact of EPL on the productivity growth gap between binding and non-binding industries, while the effect on non-binding industries is not identified. The assumption made here that EPL has no impact on productivity growth in non-binding industries - as well as the omission of any possible impact of EPL on reallocation of resources from lower to higher-productivity growth sectors - means that the simulated effects of EPL reform on productivity growth presented below should be seen as lower-bound estimates.

4. EPL-binding industries identified using this criterion are Textiles, wearing apparels and leather; Wood and wood products; Paper, printing and publishing; Coke, refined petroleum, nuclear fuel; Rubber and plastics; Non-metallic mineral products; Basic metals and fabricated metals; Machinery n.e.c.; Electrical and optical equipment; Transport equipment; Manufacturing, n.e.c. and recycling; Construction; Transport and storage; Post and telecommunication.

5. Data for Construction, Transport and storage, and Post and telecommunications are missing in the UNIDO database. For the purpose of the simulations the value added shares in GDP of these sectors are assumed to be the same as the 


\section{Effects on employment of labour tax wedge and pension reform}

The framework is based on Bassanini and Duval (2006), Tables 2.1, 2.2, and 2.3: ${ }^{6}$

$$
\begin{aligned}
& \triangle E M P R_{1524}^{*}=-0.34 \times \Delta T W, \\
& \triangle E M P R_{2554}^{M^{*}}=-0.3 \times \Delta T W, \\
& \triangle E M P R_{2554}^{F^{*}}=-0.5 \times \Delta T W, \\
& \triangle E M P R_{5564}^{*}=-0.33 \times \Delta T W, \\
& \triangle E M P R^{*}=\sum_{j} \frac{P O P_{j}}{P O P_{1564}} \Delta E M P R_{j}^{*},
\end{aligned}
$$

where $E M P R_{j}^{*}$, is the equilibrium employment rate of agents from group $j$ (in \%) and $P O P$ is the population. The first four equations relate the change in labour tax wedge to the changes in the equilibrium employment of youth, prime age male, prime age female and old age workers. The change in aggregate equilibrium employment rate is computed as weighted sum of those changes.

The actual rate of employment is assumed here to fully adjust to its long-run level in ten years.

average shares observed across the five lowest-income OECD countries (Czech Republic, Hungary, Slovak Republic, Poland, and Portugal). Likewise data for a few sectors in Ireland and for Electrical and optical equipment in China are missing and for the purpose of the simulations the shares in GDP of these sectors are assumed to be the same as the averages observed respectively in other OECD countries and in other non-OECD countries.

6. Some of the material in Bassanini and Duval (2006) was also published in Bassanini and Duval (2009). 